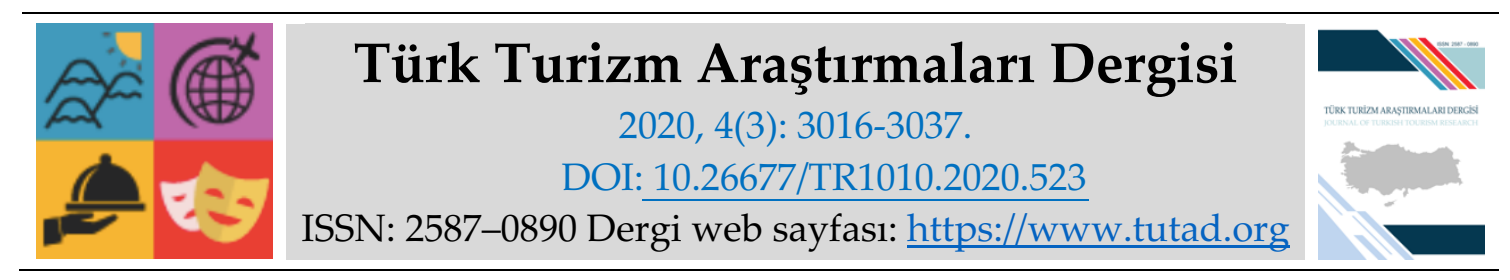

KAVRAMSAL MAKALE

\title{
Uluslararası Turizm Harcamalarının Sosyal, Kültürel ve Ekonomik Açıdan İncelenmesi
}

Arş. Gör. Dr. Cemal Ersin SİLIK, Ankara Hacı Bayram Veli Üniversitesi, Turizm Fakültesi, Ankara, e-posta: cemal.silik@hbv.edu.tr ORCID: https://orcid.org/0000-0001-8662-4188

Doç. Dr. M. Murat KIZANLIKLI, Ankara Hacı Bayram Veli Üniversitesi, Turizm Fakültesi, Ankara, e-posta: murat.kizanlikli@hbv.edu.tr ORCID: https://orcid.org/0000-0002-6953-767X

Öz

Dünyadaki turizm hareketine katılan insan sayısının artmasıyla birlikte, turistler dünyanın çeşitli yerlerine seyahat etmekte, kültürel ve sosyal etkileşime girmektedir. Bu açıdan turizm, ülkeler arasındaki ekonomik dengesizliklerin azaltılmasında ve gelişmekte olan bölgelerin kalkınmasında da önemli bir role sahiptir. Bu çalışmanın amacı, Dünya'da en fazla uluslararası turizm harcaması yapan ülkelerin ve Türkiye'nin bazı ekonomik, sosyal ve kültürel göstergeleri ile turizm harcamaları arasındaki ilişkiyi incelemektir. Çalışmada, nitel araştırma yönteminden yararlanılmıştır. T.C. Kültür ve Turizm Bakanlığı, Dünya Bankası, Ekonomik İşbirliği ve Kalkınma Örgütü (OECD), Birleşmiş Milletler Dünya Turizm Örgütü (UNWTO), Dünya Seyahat ve Turizm Konseyi (WTTC), Dünya Ekonomik Forumu gibi resmi ve küresel kuruluşların istatistikleri kullanılarak ikincil veri analizi yapılmıştır. Araştırma, ülkelerin son on bir yıllık (2009-2019) verileri kullanılarak yapılmıştır. Araştırma bulguları, en fazla uluslararası turizm harcaması yapan ülkeler ve Türkiye arasında seyahat ve turizm rekabet göstergeleri, eğitim kazanımları, çalışma süreleri, işsizlik oranları, enflasyon gibi sosyal ve ekonomik göstergeler açısından farklılıkları ortaya koymaktadır.

* Bu çalışma, 8-10 Eylül 2017 tarihleri arasında Ankara'da düzenlenen 4th International Conference on Social Sciences and Education Research'de özet bildiri olarak sunulmuştur.

Anahtar Kelimeler: Uluslararası Turizm Harcaması, Sosyal, Kültürel ve Ekonomik Göstergeler, Türkiye

Makale Gönderme Tarihi: 10.03.2020

Makale Kabul Tarihi: 02.07.2020

Önerilen Atıf:

Silik, C. E. ve Kızanlıklı, M. M. (2020). Uluslararası Turizm Harcamalarının Sosyal, Kültürel ve Ekonomik Açıdan İncelenmesi, Türk Turizm Araştırmaları Dergisi, 4(3): 3016-3037.

(c) 2020 Türk Turizm Araştırmaları Dergisi. 


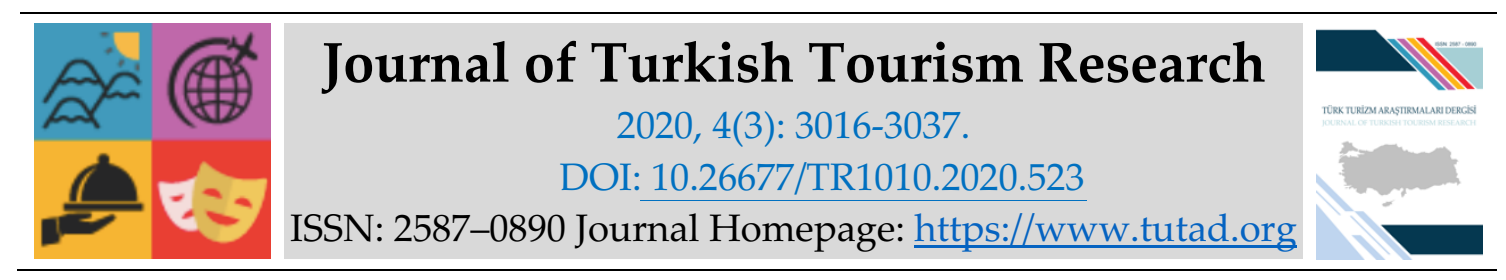

CONCEPTUAL PAPER

\title{
Social, Cultural and Economic Examination of International Tourism Expenditures
}

Dr. Cemal Ersin SİLIK, Ankara Hacı Bayram Veli University, Faculty of Tourism, Ankara, e-mail: cemal.silik@hbv.edu.tr ORCID: https://orcid.org/0000-0001-8662-4188

Associate Prof. Dr. M. Murat KIZANLIKLI, Ankara Hacı Bayram Veli University, Faculty of Tourism,_Ankara, e-mail: murat.kizanlikli@hbv.edu.tr

ORCID: https://orcid.org/0000-0002-6953-767X

\begin{abstract}
With the increasing number of people participating in the tourism movement in the world, tourists travel to various parts of the world and engage in cultural and social interaction. From this point, tourism has also an important role in reducing economic imbalances among countries and in the development of emerging regions. The aim of the study is to examine whether there is a relationship between international tourism expenditure and the economic, social and cultural figures of the World's top tourism spenders and Turkey. Qualitative research method was used in the research. Secondary data analysis was carried out by using the statistics of official and global organizations such as Rep. of Turkey Ministry of Culture and Tourism, The World Bank, The Organisation for Economic Co-operation and Development (OECD), World Tourism Organization (UNWTO), World Travel and Tourism Council (WTTC), World Economic Forum. The research was carried out using the data of the last eleven years (2009-2019) of the countries. According to the findings, there are differences between Turkey and top tourism spenders regarding some travel and tourism competitiveness pillars and social and economic indicators such as educational attainment, working times, unemployment rates, inflation.
\end{abstract}

Keywords: International Tourism Expenditure, Social, Cultural and Economic Indicators, Turkey Received: 10.03 .2020

Accepted: 02.07.2020

Suggested Citation:

Silik, C. E. and Kızanlıklı, M. M. (2020). Social, Cultural and Economic Examination of International Tourism Expenditures, Journal of Turkish Tourism Research, 4(3): 3016-3037.

(C) 2020 Türk Turizm Araştırmaları Dergisi. 


\section{Gíriş}

Turizm, sosyal, kültürel ve ekonomik katkıları ile birlikte ülkeler için önemli bir sektördür. Uluslararası seyahat eden turist sayısı bir önceki yıl ile karşılaştırıldığında, 2019 yılında \% 3,8 büyüme göstererek 1,5 milyar kişiye ulaşmıştır. Bununla birlikte, dünya genelindeki turizmden elde edilen ihracat kazancı da (uluslararası turizm gelirleri ve yolcu taşımacılığı ile birlikte) \%4 artış göstererek 1,7 trilyon (toplam ihracatın \%7'si, küresel hizmet ihracatının da \% 29'u) dolara yükselmiştir. Aynı zamanda 2019 yılı, Thomas Cook'un ve Avrupa'daki birkaç düşük maliyetli havayolunun çöküşüyle sektörde büyük değişimlerin yaşandığı bir yıl olmasına rağmen, Dünya Turizm Örgütü'nün verilerine göre, sürdürülebilir büyümenin art arda gerçekleştiği onuncu yıl olarak değerlendirilmektedir (UNWTO, 2020).

Turizm sektörü, ekonomisine güçlü bir şekilde katkıda bulunan birçok ülke için ana gelir kaynağı haline gelmiştir (Bernini ve Cracolici, 2015). Turist akışlarının ekonomiler üzerindeki etkisi genellikle kayda değerdir ve küçük topluluklardan büyük ülkelere kadar ekonomik büyüme için önemli bir anahtar teşkil etmektedir (Brida ve Scuderi, 2013). Turizme olan ekonomik talep mikro veya makro düzeyde incelenebilir. Her iki düzeyde de talep, çok sayıda ekonomik, sosyal, politik ve psikolojik faktörden etkilenmektedir. Makroekonomik düzeydeki turizm talebi çalışmaları, genellikle toplam varış ve harcama gibi toplu talep verilerinin analizi ile ilgilidir (Wang ve Davidson, 2010).

Yapılan çalışmalar, harcamaların, seyahat edenlerin rrk/etnik köken (Cannon ve Ford, 2002; Chhabra vd., 2002), ikamet yeri/milliyet (Asgary vd., 1997; Perez ve Juaneda, 2000), tam zamanlı çalışma (Thrane, 2002) gibi karmaşık sosyal demografik özelliklerinden etkilendiğini göstermektedir. Wang ve diğerleri (2006) sosyo demografik, seyahate bağlı ve psikografik değişkenlerin, seyahat harcamaları üzerindeki etkilerini incelemiş, gelir ve gezi ile ilgili özelliklerin turizm harcamalarını etkileyen en etkili değişkenler olduğunu belirtmiştir. Hane halkı gelirinin, harcama kategorilerinin çoğu için harcama modellerini etkileyen en önemli faktör olduğu bulunmuştur. Turizm harcamaları tipik olarak, turizmin yerel ekonomi üzerindeki etkisini izlemek ve değerlendirmek için politika yapıcılar, planlama yetkilileri, pazarlamacılar ve araştırmacılar tarafından incelenmektedir (Wang vd., 2006). Turizme uygulanan tüketici talep teorisi, turizm talebinin miktarının nüfus, gelir, fiyatlar, tüketicilerin zevki, pazarlama ve diğer sosyal, kültürel, coğrafi ve politik faktörlerle yakından ilgili olduğunu göstermektedir (Witt ve Witt, 1995).

Dünya Turizm Örgütü tarafından 2011 yılında hazırlanan turizmin geleceğine yönelik raporda, 2020 yılına kadar 1,4 milyar kişinin, 2023 yılına kadar 1,5 milyar kişinin ve 2030 yılına kadar da 1,8 milyar kişinin uluslararası turizm faaliyetlerine katılacağına yönelik beklentiler belirlenmiştir. Yapılan değerlendirme sonucunda, 2023 yılına kadar ulaşılması hedeflenen 1,5 milyar uluslararası seyahat eden kişi sayısına 2019 yılı sonu itibariyle ulaşıldığı görülmektedir. Bu sonuçlar, uluslararası seyahate katılım oranının hızlı bir büyüme gösterdiğini ve hedeflere daha erken ulaşıldığını ortaya koymaktadır. Bu nedenle, turizm sektöründen ciddi gelir elde eden ülkelerin, mevcut pastadan daha fazla pay alabilmek için proaktif yaklaşımlar sergilemesi gerekliliği ön plana çıkmaktadır.

Turizm sektörüne yapılan yatırımlarda, başta ekonomik olmak üzere, sosyal, kültürel ve çevresel etkiler de bulunmaktadır. Bu nedenle çalışmada, ülkelerin uluslararası turizm harcamaları ile sosyal, kültürel ve ekonomik göstergeleri arasındaki ilişki incelenmiştir. Ayrıca çalışmada, makro düzeyde, sosyal, kültürel ve ekonomik yaklaşımla uluslararası turizm harcamalarının kapsamlı ve dikkat çekici bir görünümü sunularak, ülkeler arasında karşılaştırma yapılmış ve literatüre katkı sağlanması amaçlanmıştır. 


\section{KAVRAMSAL ÇERÇEVE}

\section{Turizm Harcamalarının Sosyal, Kültürel ve Ekonomik Etkileri}

Turizm harcamalarına yönelik yapılan önceki çalışmalar (Hong vd., 1996; Kim ve Prideaux, 2005; Wang ve Davidson, 2010; Eugenio-Martin ve Campos-Soria, 2011, 2014; Hung vd., 2012; Abbruzzo vd., 2014; Gholipour ve Tajaddini, 2014; Gholipour vd., 2014; Wang, 2014; Nunes Valença vd., 2015; Bernini ve Cracolici, 2015; Lin vd., 2015; Marrocu vd., 2015; Konstantakis vd., 2017); sosyal, kültürel, ekonomik, çevresel, demografik, seyahat temelli ve psikolojik özellikler bakımından incelenmiştir (Olya ve Mehran, 2017: 148). Bununla birlikte turizm harcamalarına yönelik son dönemlerde yapılan çalışmalarda; spor turizminin turizm harcamalarındaki yeri (Rudkin ve Sharma, 2019), ekonomik ve sosyal kaygı ile turizm harcamaları arasındaki ilişki (Mehran ve Olya, 2018), turizm harcamaları kapsamında yerli-yabancı ziyaretçi karşılaştırması yapılarak yeniden ziyaret ve ağızdan ağza pazarlama ilişkisi (Larsen ve Wolff, 2019), turizm talebi ile turizm harcamaları arasındaki ilişki (Rossello-Nadal ve He, 2019), turizm harcamalarına yönelik dağılım modellemesi (Gomez-Deniz ve Perez-Rodriguez, 2018), turizm harcama davranışı ve memnuniyet ilişkisi (D’Urso vd., 2020), turizm harcamalarının pazar segmentlerine göre ilişkisi (Perez-Rodriguez ve Ledesma-Rodriguez, 2019) incelenmiştir.

Yapılan literatür taraması sonucunda ilk olarak; turizm harcamalarını etkileyen en önemli faktörlerden birisinin gelir olduğu sonucuna varılmıştır. Bununla birlikte, hane halkı gelirinin turizm harcamaları ile doğrudan ilişkili olduğu ifade edilmektedir (Downward ve Lumsdon, 2003, 2004). Abbruzzo vd., (2014) tarafından yapılan çalışmada, bütçe kısıtlamalarının, İspanyol hane halkının turizm faaliyetlerine katılmalarında önemli bir engel oluşturduğu sonucuna varılmıştır. Diğer taraftan Wang (2014), altı farklı coğrafi bölgede, kişi başına düşen Gayri Safi Yurtiçi Hâsıla (GSYH) ile uluslararası turizm harcamaları arasındaki ilişkiyi araştırmıştır. Araştırma sonuçları, ihtiyati tasarruf seviyesinin yüksek olduğu bölgelerdeki hane halkının, tatil seyahatlerini lüks bir tüketim malı olarak algılamasından dolayı, turizm harcamalarına yer ayırmadıklarını göstermektedir. İkinci olarak; yaş, eğitim durumu, cinsiyet, medeni hal, uyruk, ikamet yeri, dil, meslek, ırk ve etnik köken gibi sosyo-demografik özelliklerin de turizm harcamaları üzerindeki etkileri belirlenmiştir. Bu özellikler arasında yaş faktörünün, en önemli etki düzeyine sahip faktörlerden birisi olduğu ifade edilmektedir. Bernini ve Cracolici (2015) tarafından yapılan çalışmada, toplumdaki demografik değişikliklerin turizm karar alma süreçlerine etkisi incelenmiştir. Çalışma sonuçları, yaşlanma ve kuşak etkisinin, bireylerin tatil etkinliklerine katılma kararı ve harcama istekliliği üzerindeki etkisini belirtmektedir. Üçüncü olarak; konaklama, etkinlikler, destinasyon, seyahat bilgi kaynakları, kalış süresi, ulaşım araçları, rezervasyon ve planlama süreci, geçmiş seyahat deneyimleri, amaç, seyahat mesafesi, ziyaretçilerin tipolojisi gibi seyahat temelli özelliklerin de turizm harcamaları üzerinde etkili olduğunu yapılan çalışmalar (Jang vd., 2004; Aguilo vd., 2017) ortaya koymaktadır. Son olarak; Kim ve Prideaux (2005) tarafından yapılan çalışmada, genel görüş ve tutumlar, seyahat hakkındaki görüşler ve seyahat motivasyonları gibi psikolojik özelliklerin turizm harcamalarındaki farklılıkları açıklayabileceği ifade edilmektedir (Wei vd., 2018:783).

Turizm harcamalarını etkileyen faktörler arasında kalış süresi ve seyahat grubunun büyüklüğü de yer almaktadır. Literatürde yer alan bazı çalışmalar (Agarwal ve Yochum, 1999; Mok ve Iverson, 2000; Wang vd., 2006; Fredman, 2008; Kim vd., 2008; Kozak vd., 2008; Thrane ve Farstad, 2011; Aguilo vd., 2017; Aguilar ve Diaz, 2019; Qiang vd., 2019; Rahman vd., 2019) ziyaretçilerin kalış süreleri ile turizm harcamaları arasında pozitif bir etki olduğunu açıklamaktadır. Seyahat grubu büyüklüğü ile turizm harcamaları arasındaki ilişkiye bakıldığında ise, yapılan çalışmalar (Mak vd., 1977; Taylor vd., 1993; Mok ve Iverson, 2000) iki değişken arasında negatif bir ilişki olduğunu göstermektedir (Thrane ve Farstad, 2011:49). 


\section{Literatür İncelemesi}

Literatür incelemesi kapsamında, uluslararası turizm harcamaları konu başlığında yapılmış önemli araştırmalara değinebilmek ve ulaşılabilirlik açısından "Web of Science" indeksi kapsamındaki dergiler taranmıştır. Bu kapsamda incelenen çalışmalar, kısaca amaç ve bulgularından bahsedilmek koşulu ile aşağıda sunulmuştur.

İsveç'te bulunan dağlık bölgeye gelen ziyaretçilerin (kayakçılar, sırt çantalılar, kar aracı kullanıcıları ve genel ziyaretçiler) turizm harcamalarını etkileyen faktörleri belirlemeye yönelik Fredman (2008) tarafından yapılan çalışmada, destinasyon bölgesinde ve destinasyon bölgesi dışındaki turizm harcamalarında etkili olan faktörler belirlenmiştir. Çalışma sonucunda; konaklama süresi, hane halkı geliri, aktivite seçimi, meslek, organize bir tura katılma ve konaklama seçimi destinasyon bölgesindeki turizm harcamalarını etkileyen faktörler olarak belirlenmiştir. Bununla birlikte; cinsiyet, seyahat şekli, uzaklık ve aktivitenin önemi de destinasyon bölgesi dışındaki turizm harcamalarında etkili olan faktörler olarak tespit edilmiştir.

2007-2009 yılları arasındaki yaz döneminde Norveç'e gelen yabancı turistlerin milliyetleri ile harcama seviyelerindeki değişiklikler Thrane ve Farstad (2012) tarafından incelenmiştir. Turizm harcamalarındaki bir değişken olarak milliyetin incelendiği çalışmada, milliyetin hem brüt hem de net harcamalar üzerindeki etkileri, sadece turizm harcamalarında açıklanan toplam varyansın \% 35'inden fazlasını oluşturmaktadır. Ayrıca Thrane ve Farstad (2011) tarafından Norveç'te yapılan başka bir çalışmada ise, ziyaretçilerin destinasyondaki kalış süreleri ve seyahat grubunun büyüklügü ile turizm harcamaları arasındaki ilişki incelenmiştir. Çalışma sonuçları, kalış süreleri ile turizm harcamaları arasında pozitif bir ilişki olduğunu, seyahat grubunun büyüklüğü ile turizm harcamaları arasında da dışbükey (negatif-anlamlı olmayan) bir ilişki tespit edilmiştir. Özetle, kalış sürelerindeki \% 10'luk bir artışın, turizm harcamalarında \% 6,4'lük bir artış; seyahat grubu büyüklügündeki \% 10'luk bir artışın ise, turizm harcamalarında \% 1,6'lık bir azalma oluşturduğu saptanmıştır. Seyahat grubu büyüklüğü ile turizm harcamaları arasındaki negatif ilişki farklı çalışmalar (Mak vd., 1977; Taylor vd., 1993; Mok ve Iverson, 2000) ile de desteklenmiştir (Thrane ve Farstad, 2011:49).

Turizm harcamalarında etkili olan sosyo-ekonomik faktörlerin incelendiği çalışmada Vietze (2011), turizm harcamalarının, kişi başına düşen turizm gelirleri ile doğru orantılı olduğunu ortaya koymaktadır. Çalışma sonuçları, demokratik ülkelerdeki insanların yurtdışına seyahat etmek için daha fazla harcama yaptıklarını ortaya koymaktadır. Bu sonuçlardan hareketle, gelişmekte olan ülkelerin turizm sektörüne yatırım yapmaları önerilmektedir.

Marcussen (2011) tarafından yapılan çalışmada, 1995-2009 yılları arasında akademik dergilerde yayınlanan 50'den fazla makaleye kesitsel çalışma yapılmış ve turist harcamalarındaki faktörler meta-analiz yoluyla incelenmiştir. Çalışma sonucunda, "kişi başı gecelik harcama modeli" kapsamında 18 faktörün tamamı anlamlı bulunmuştur. Alegre vd., (2013) tarafından, 2006-2010 yılları arasında, İspanya'da hane halkının turizme katılım kararları ve turizm harcamaları incelenmiştir. 2008 yılını (krizin başlangıcı) referans alarak, turizm harcamaları modelindeki istikrar test edilmiş ve kriz zamanlarında etkileri değişen faktörler belirlenmiştir. Çalışma sonucunda, işsizlik faktörünün turizm harcamaları üzerinde önemli bir açıklayıcı güce sahip olduğu belirlenmiştir.

Wang (2014) tarafından yapılan çalışmada, gelirlerin farklı tasarruf rejimleri altında turizm harcamaları üzerindeki etkisi değişiklik göstermektedir. Elde edilen sonuçlar, düşük tasarruf rejiminde, kişi başına düşen Gayri Safi Yurtiçi Hasıla'daki (GSYIH) artışın, uluslararası turizm harcamaları üzerindeki etkisinin daha belirgin olduğunu göstermektedir. Yüksek tasarruf rejiminde ise, ihtiyati tasarruflar için güçlü bir motivasyon bulunduğundan dolayı turizmin lüks 
bir ihtiyaç olduğu düşünülmektedir. Bu nedenle, bu tür harcamalar, kişi başına düşen Gayri Safi Yurtiçi Hâsıla (GSYİH) arttıkça artış göstermektedir.

Turizm sektörünün harcama odaklı bir faaliyet olduğu düşünüldüğünde, turizm harcamalarının hayati bir öneme sahip olduğu söylenebilir (Mihalic, 2002:88). Turizm harcamalarının iyi bir şekilde ortaya konulması, uygun pazar bölümlerinin belirlenmesinde ve turizm sektörü için pazar bölümlendirme stratejilerinin oluşturulmasında etkilidir. Turizm harcamalarının önemi, sadece turizmle ilgili işletmeler tarafından değil, aynı zamanda yerel yönetimler ve destinasyon pazarlama örgütleri tarafından da kabul edilmelidir (Lin vd., 2015:101). Turizm, harcamalar ve karakteristik özellikler arasındaki ilişkilere yönelik önemli ekonometrik teknikler bulunmaktadır (Brida ve Scuderi, 2013). Bununla birlikte, turizm harcamalarına yönelik yapılan deneysel araştırmalar sınırlı sayıdadır (Lin vd., 2015:101). Lin vd., (2015) tarafından Çin Ulusal Hanehalkı verileri kullanılarak yapılan çalışmada, turizm sektöründeki hane halkı harcama modellerinin farklı yaşam evrelerinde analiz edilmesi amaçlanmıştır. Elde edilen sonuçlar, orta yaşlıların, toplam turizm harcamalarının ve özellikle de grup dışı tur harcamalarının diğer yaş gruplarına göre yüksek olduğunu ortaya koymaktadır.

Thrane (2015) tarafından Norveçli üniversite öğrencilerine yönelik yapılan çalışmada, seyahat özelliklerinin, öğrencilerin turizm harcamaları üzerindeki en önemli belirleyici olduğu tespit edilmiştir. Ayrıca seyahat edilen destinasyon ve kalış süreleri ile turizm harcamaları arasında pozitif yönlü bir ilişki bulunmuştur. Elde edilen sonuçlara göre; iç turizmin diş turizme, kısa süreli konaklamaların uzun süreli konaklamalara kıyasla daha az maliyetli olmasından dolayı, turizm harcamaları da azalmaktadır. Bernini ve Cracolici (2015) tarafından yapılan çalışmada ise, yaş faktörü, seyahat etme niyeti üzerinde olumsuz etkiye sahip iken, turizm harcamaları üzerinde olumlu bir etkiye sahiptir. Çalışma sonuçları, yaşlı kesimin seyahat eğiliminde olduğunu fakat düşük turizm harcamalarına da sahip olduğunu ortaya koymaktadır.

Nunes Valença ve diğerleri (2015) tarafından yapılan çalışmada, Brezilya'daki döviz kuru ile turizm harcamaları arasındaki ilişki incelenmiştir. Yapılan çalışmada, Ocak 1994-Aralık 2014 arasındaki aylık veriler incelenerek analiz yapılmıştır. Analiz sonuçları, döviz kuru ile turizm harcamaları arasında nedensel bir ilişki olduğunu ifade etmektedir. Bulgular, Brezilyalıların yurtdışındaki turizm harcamalarının, döviz kurundaki dalgalanmalar açısından, Brezilya'yı ziyaret eden yabancıların ürettiği turizm gelirlerinden daha fazla etkilendiğini ortaya koymaktadır (Wanke vd., 2019:5).

Eugenio-Martin ve Inchausti-Sintes (2016) tarafından yapılan çalışmada, turistlerin çıkış destinasyonlarındaki seyahat maliyetlerine yönelik tasarruflarının, varış destinasyonlarındaki yüksek turizm harcamalarına aktarıldığı belirlenmiştir. Kanarya Adaları örneğinde elde edilen sonuçlar, seyahat maliyetlerindeki \% 10,3 ile \% 46,1 arasındaki değişen tasarruf oranının turizm harcamalarına aktarıldığını göstermektedir. Konstantakis vd., (2017) tarafından turizm harcamaları ve krizler üzerine yapılan çalışmada, turizm harcamalarının Gayri Safi Yurtiçi Hâsıla (GSYIHH) üzerindeki etkileri, geliştirilen bir model aracılığı ile test edilmiştir. Araştırma sonuçları, daha az gelişmiş ekonomilerin, baskın ekonomilerin turizm harcamalarındaki değişikliklere karşı oldukça savunmasız olduğunu göstermektedir.

Aguilo vd., (2017) tarafından yapılan çalışmada, literatürdeki çalışmalara benzer bir şekilde, yüksek hane halkı geliri ile yüksek harcama davranışı ve destinasyonda daha fazla kalma süresi arasında pozitif ilişki tespit edilmiştir. Ayrıca, Mallorca'daki yerli ziyaretçilerin yabancı ziyaretçilere oranla daha az kalış süresine sahip oldukları belirlenmiştir. Yapılan harcamalar karşılaştırıldığında ise, İngiliz ziyaretçilerin, eğlence ve ulaşım noktasında diğer milliyetlerden gelen ziyaretçilere kıyasla daha az harcama yaptıkları; bununla birlikte, restoran ve yiyecekiçecek noktasında ise daha fazla harcama yaptıkları tespit edilmiştir. 
İlgili çalışmalar incelendiğinde, turizm harcamalarına yönelik nicel ve nitel farklı çalışmalar ile literatüre katkı sağlandığı görülmektedir. Yapılan incelemeler sonucunda elde edilen en önemli faktörlerden birisi, daha az gelişmiş ekonomiye sahip ülkelerin, baskın (gelişmiş) ekonomiye sahip ülkelerin turizm harcamalarındaki değişmelerden oldukça sert etkilenmesidir. Yani gelişmiş ekonomilerin (Çin, ABD, Almanya vb.) turizm harcamalarında yıllar itibariyle meydana gelen artı̧, gelişmekte olan veya az gelişmiş ülkeleri savunmasız bırakmaktadır.

Ülkelerin yıllar itibariyle (2009-2019) turizm harcamaları detaylı bir şekilde Tablo 1'de yer almaktadır. Güçlü ekonomiye sahip olan Çin, ABD ve Almanya'nın özellikle 2013 yılından sonra turizm harcamalarına ciddi miktarlarda pay ayırması, diğer ülkelerin bu alanda rekabet edebilirliğini azaltmaktadır. Ülkelerin turizm sektörü için yapmış oldukları harcamalar, döviz kurları, gayri safi yurt içi hâsıla, turizm gelirleri gibi değişkenler ile de doğru orantılıdır. Tablo 3'de ülkelerin GSYH ve kişi başına düşen GSYH miktarları ayrıntılı bir biçimde verilmiştir. Ortaya çıkan durum, kişi başına düşen GSYH miktarı fazla ülkelerin, turizm harcamalarına ayırdıkları miktarların da fazla olduğunu göstermektedir.

$\mathrm{Bu}$ değişkenlerin dışında, turistler açısından turizm harcamalarını etkileyen faktörlere bakıldığında, kalış süresinin en önemli faktörlerden birisi olduğu anlaşılmaktadır. Bununla birlikte sonuçlar, demokratik ülkelerde yaşayan vatandaşların, demokratik olmayan ülkelerde yaşayan vatandaşlara göre uluslararası turizme daha fazla pay ayırdığını göstermektedir. Literatürden elde edilen sonuçlar açı bir şekilde, turizm harcamalarının sadece ekonomik değil aynı zamanda sosyal ve kültürel değişkenlerden de etkilendiğini ortaya koymaktadır. Bu nedenle çalışmada, turizm harcamalarının ekonomik ilişkisinin yanında sosyal, kültürel ve çevresel ilişkisi de incelenmiştir.

\section{YÖNTEM}

Araştırmanın amacı doğrultusunda, en fazla uluslararası turizm harcaması yapan ülkelerin turizm harcamaları, sosyal, kültürel ve ekonomik göstergeleri başta olmak üzere bazı değişkenler incelenmiştir. Bu kapsamda ülkelerin, uluslararası turizm harcaması, uluslararası turizme katılım, kişi başına düşen GSYH miktarı, seyahat ve rekabet edebilirlik endeksi sıralaması, enflasyon oranı, işsizlik oranı, harcanabilir gelir, eğitim durumu, yaşam memnuniyeti gibi sosyal, kültürel ve ekonomik göstergeleri incelenmiştir.

Çalışmada, nitel araştırma yöntemi kullanılmıştır. Değişkenlere yönelik bilgi (veri) toplamak için ikincil verilerden yararlanılmıştır. İkincil veriler, araştırmacının üzerinde durduğu konuyla alakalı çeşitli organizasyonların yaptıkları araştırmalar sonucunda oluşturdukları veri setleri olarak ifade edilmektedir. İkincil veri türleri, nitel, nicel, betimleyici veya açıklayıcı çalışmalarda kullanılabilmektedir (Altunışık vd., 2010:73).

İkincil verileri elde edebilmek için, T.C. Kültür ve Turizm Bakanlığı, Dünya Bankası, Ekonomik İşbirliği ve Kalkınma Örgütü (OECD), Birleşmiş Milletler Dünya Turizm Örgütü (UNWTO), Dünya Seyahat ve Turizm Konseyi (WTTC), Dünya Ekonomik Forumu ve Uluslararası Para Fonu (IMF) gibi resmi ve küresel kuruluşların istatistiklerinden faydalanılmıştır. Bu çerçevede, ilgili ülkelere ait son on bir yıllık (2009-2019) veriler incelenerek değerlendirme yapılmıştır. Her bir değişkene yönelik veriler, ilgili kurumların raporlarından derlenerek hazırlanmıştır.

\section{BULGULAR}

Araştırma bulguları ülkelerin, uluslararası turizm harcamalarını, uluslararası turizme katılımlarını, nüfuslarını, GSYH ve kişi başı GSYH miktarlarını, seyahat ve turizm rekabet 
edebilirlik endeksi puan, gösterge ve sıralamalarını ortaya koymaktadır. Bu kapsamda Tablo 1'de, en fazla uluslararası turizm harcaması yapan ülkeler ile Türkiye'nin son on bir yıldaki (20092019) uluslararası turizm harcama miktarları yer almaktadır.

Tablo 1. Uluslararası Turizm Harcamaları (2009-2019)

\begin{tabular}{|c|c|c|c|c|c|c|c|c|c|c|c|c|}
\hline \multirow[t]{2}{*}{ Sr } & \multirow[t]{2}{*}{ Ülkeler } & \multicolumn{11}{|c|}{ Uluslararası Turizm Harcamaları (Milyar \$) 2009-2019 } \\
\hline & & 2009 & 2010 & 2011 & 2012 & 2013 & 2014 & 2015 & 2016 & 2017 & 2018 & 2019 \\
\hline 1 & Çin & 43,7 & $54,9 \triangle$ & $72,6 \Delta$ & $102,0 \Delta$ & $128,6 \triangle$ & $234,7 \Delta$ & $249,8 \triangle$ & $261,1 \Delta$ & $257,7 \nabla$ & $277,3 \triangle$ & $262,1 \nabla$ \\
\hline 2 & ABD & 74,1 & $75,5 \triangle$ & $78,2 \Delta$ & $83,5 \wedge$ & 86,2 - & $105,5 \Delta$ & $114,7 \triangle$ & $123,6 \triangle$ & $135 \Delta$ & $186,5 \Delta$ & $184,2 \nabla$ \\
\hline 3 & Almanya & 81,2 & $78,1 \vee$ & $85,9 \wedge$ & $81,3 \nabla$ & $85,9 \Delta$ & $93,3 \triangle$ & $77,5 \nabla$ & $79,8 \wedge$ & 89,1 A & 104,2 A & $104,8 \Delta$ \\
\hline 4 & Birleşik K. & 50,1 & $50,0 \nabla$ & $51,0 \Delta$ & $51,3 \Delta$ & $52,6 \wedge$ & $62,6 \wedge$ & $63,3 \wedge$ & $63,6 \wedge$ & $71,4 \Delta$ & $68,8 \nabla$ & $90,2 \Delta$ \\
\hline 5 & Fransa & 38,5 & $38,5-$ & $44,1 \mathbf{\Delta}$ & $39,1 \nabla$ & $42,4 \Delta$ & 48,7 А & $39,3 \nabla$ & $40,5 \Delta$ & $41,4 \Delta$ & $57,9 \triangle$ & $56,2 \nabla$ \\
\hline 6 & Avusturalya & 17,6 & 22,2 A & $26,7 \wedge$ & $28,0 \triangle$ & $28,4 \wedge$ & $26,4 \nabla$ & $23,8 \nabla$ & $24,9 \triangle$ & 34,2 А & $42,3 \wedge$ & $43,8 \triangle$ \\
\hline 7 & Kanada & 24,2 & $29,6 \triangle$ & $33,3 \Delta$ & $35,0 \triangle$ & $35,2 \triangle$ & $33,8 \nabla$ & $30,1 \nabla$ & $29,1 \nabla$ & $31,8 \Delta$ & $33,5 \Delta$ & 42,2 А \\
\hline 8 & Rusya & 20,9 & $26,6 \Delta$ & $32,9 \Delta$ & $42,8 \Delta$ & $53,5 \Delta$ & $50,4 \nabla$ & $34,9 \nabla$ & $27,6 \nabla$ & $31,1 \Delta$ & $38,7 \Delta$ & $35,2 * \nabla$ \\
\hline 9 & Kore C. & 16,3 & $20,7 \triangle$ & $22,1 \Delta$ & $22,9 \Delta$ & $24,4 \Delta$ & $23,2 \nabla$ & $25,3 \wedge$ & $26,6 \Delta$ & $30,6 \Lambda$ & $34,7 \Delta$ & $33,5 \nabla$ \\
\hline 10 & İtalya & 27,9 & $27,1 \nabla$ & $28,7 \wedge$ & $26,4 \nabla$ & $27,0 \Delta$ & $28,8 \wedge$ & $24,4 \nabla$ & $25,0 \Delta$ & $27,7 \Delta$ & $37,6 \Delta$ & $36,4 \nabla$ \\
\hline \multirow[t]{2}{*}{$\ldots$} & Türkiye & 5,0 & $5,8 \wedge$ & $5,3 \nabla$ & $4,5 \nabla$ & $5,2 \Delta$ & $5,4 \triangle$ & $5,6 \triangle$ & $5,0 \nabla$ & $5,1 \Delta$ & $4,9 \nabla$ & $4,4 \nabla$ \\
\hline & $\begin{array}{l}\text { Hong Kong } \\
\text { (Çin) }\end{array}$ & 15,5 & $17,3 \Delta$ & $19,0 \triangle$ & $20,0 \Delta$ & 21,2 A & $22,0 \triangle$ & $23,1 \Delta$ & 24,2 А & $25,3 \triangle$ & $26,4 \Delta$ & $26,5^{*} \Delta$ \\
\hline
\end{tabular}

Kaynak: www.unwto.org, www.data.worldbank.org, www.statisca.com

* Illk üç çeyrek verilerini kapsamaktadır.

А : Bir önceki yıl ile kıyaslandı̆̆ında artış, $\quad \nabla$ : Bir önceki yıl ile kıyaslandı̆̆ında azalış

Tablo 1 incelendiğinde, son on bir yıldaki (2009-2019) uluslararası turizm harcamalarının genel bir artış halinde olduğu görülmektedir. Özellikle 2013 yılında, tabloda yer alan tüm ülkelerin uluslararası turizm harcama miktarlarında bir önceki yıla göre artış yaşanmıştır. Fakat ardından gelen 2014 ve 2015 yillarında Avustralya, Kanada ve Rusya'da art arda azalmalar meydana gelmiştir. Sınırlılık kapsamında tabloda yer almayan fakat incelenmesi gereken başka bir durum da 2009 yılında yaşanmıştır. 2009 yılı verileri bir önceki yıl ile karşılaştırıldığında, ülkelerin uluslararası turizm harcamaları (Çin ve Türkiye hariç) genel bir azalma göstermiştir. 2009 yılındaki ülkelerin turizm harcamalarında yaşanan genel azalışta, 2008 yılındaki küresel ekonomik krizin etkileri olduğu söylenebilir.

Uluslararası turizm harcamaları bakımından 2019 yılı verileri ele alındığında ise, ilk sırada 262,1 milyar dolar ile Çin bulunmaktadır. Ardından sırasıyla ABD (184,2 milyar dolar), Almanya (104,8 milyar dolar) ve Birleşik Krallık (90,2 milyar dolar) gelmektedir. 2019 yılı itibari ile ilk sırada yer alan Çin, özellikle 2014 yılı ile birlikte ciddi bir yükseliş ortaya koymaktadır. Fakat 2019 yılına gelindiğinde, ülkelerin turizm harcamaları bir önceki yıla göre genel bir düşüş seyri izlemiştir. 2019 yılı verilerinde, Hong Kong (Çin) ve Rusya'ya ait veriler, ilk üç çeyreğe (Ocak-Eylül) ait verilerdir. Küresel boyutta yaşanan ekonomik krizlerin, özellikle 2019 yılından itibaren ülkeler açısından daha derinden hissedilmesi, düşüş eğiliminin nedeni olarak değerlendirilebilir.

Küresel boyutta son on bir yılın (2009-2019) verileri dikkate alındığında, özellikle Çin başta olmak üzere, Çin ve ABD'nin turizm harcamaları noktasında lider ülkeler konumunda oldukları görülmektedir. Bu iki ülkenin ardından ise, Almanya ve Birleşik Krallık gelmektedir. Tabloda yer alan ülkeler incelendiğinde, Çin'e ayrı bir vurgu yapılması gerekmektedir. Çünkü Çin, 2009 yılında 43,7 milyar dolar olan turizm harcamasını, 2019 yılında yaklaşık 262,1 milyar dolara yükseltmiştir. Diğer ülkeler ile mukayese edildiğinde Çin, son on bir yılın en fazla yükseliş gösteren ülkesi konumundadır.

Türkiye'ye ait veriler incelendiğinde ise, 2009 yılında 5 milyar dolar olan turizm harcamasının, 2019 yılında 4,4 milyar dolara gerilediği görülmektedir. Tabloda yer alan tüm ülkeler ile 
kıyaslama yapıldığında, 2019 yılındaki uluslararası turizm harcaması, 2009 yılındaki turizm harcamasından düşük olan tek ülkenin Türkiye olduğu görülmektedir. Türkiye özelinde, 20092017 yılları arasındaki uluslararası turizm harcamalarında kısmi yükselişler yaşansa da ciddi bir artış yaşanmamıştır. Özellikle 2017 yılından itibaren ise, Türkiye'nin uluslararası turizm harcamaları azalma göstermektedir. Bu sonuçlar incelendiğinde, Türkiye'de yaşanan düşüş eğiliminin altında yatan nedenlerin araştırılması gerekliliği ortaya çıkmaktadır. Orta Doğu'da (özellikle Suriye'de) yaşanan krizler ve bunun yansıması olarak da ekonomik krizler ülkelerin bütçelerinden ayırdıkları payları etkilemektedir. Orta Doğu'da yaşanan kriz süreci tüm Avrupa'yı etkilese de en fazla etkilenen ülkelerden birisi Türkiye olmuştur. Coğrafi konumu itibari ile Türkiye bu kriz sürecini daha yakından hissetmektedir. Ortaya çıkan bu tablonun, Türkiye'nin uluslararası turizm harcamalarına ayırdığı miktarları olumsuz etkilediği söylenebilir. Hatta özellikle 2020 yılında tüm dünyayı etkisi altına alan Covid-19 salgınının, 2020 yılından itibaren tüm ülkelerin uluslararası turizm harcamalarına olumsuz etki yapacağı da öngörülmektedir. Tablo 2' de ise araştırmada ele alınan ülkelerin, 2009-2019 yılları arasındaki uluslararası turizme katılım sayıları yer almaktadır.

Tablo 2. Uluslararası Turizme Katılım (2009-2019)

\begin{tabular}{|c|c|c|c|c|c|c|c|c|c|c|c|c|}
\hline \multirow[t]{2}{*}{$S r$} & \multirow[t]{2}{*}{ Ülkeler } & \multicolumn{11}{|c|}{ Uluslararası Turizme Katılım (Milyon kişi) 2009-2019 } \\
\hline & & 2009 & 2010 & 2011 & 2012 & 2013 & 2014 & 2015 & 2016 & 2017 & 2018 & 2019 \\
\hline 1 & Çin & 47,6 & $57,3 \Delta$ & $70,2 \Delta$ & $83,1 \Delta$ & $98,1 \Delta$ & $116,5 \Delta$ & $127,8 \Delta$ & $135,1 \Delta$ & $143 \Delta$ & $149,7 \Delta$ & $169,2 \Delta$ \\
\hline 2 & ABD & 62,1 & $61,0 \nabla$ & $59,2 \nabla$ & $60,6 \triangle$ & $61,3 \wedge$ & $68,1 \triangle$ & $75,1 \Delta$ & $80,2 \wedge$ & $87,7 \Delta$ & $92,5 \Delta$ & $83,4 \nabla$ \\
\hline 3 & Almanya & 85,5 & $85,8 \Delta$ & $84,6 \nabla$ & $82,7 \nabla$ & $87,4 \Lambda$ & $83,0 \nabla$ & $83,7 \Delta$ & $90,9 \Delta$ & $92,4 \Delta$ & $108,5 \Delta$ & $110,6^{*} \Delta$ \\
\hline 4 & Birleşik K. & 58,6 & $55,5 \nabla$ & $56,8 \Delta$ & $56,5 \nabla$ & 57,7 А & $60,0 \Delta$ & $65,7 \wedge$ & $70,8 \Delta$ & $74,1 \Delta$ & $70,3 \nabla$ & $72,6 \Delta$ \\
\hline 5 & Fransa & 25,1 & $25,0 \nabla$ & $26,1 \wedge$ & $25,3 \nabla$ & $26,0 \Delta$ & $27,9 \Delta$ & $26,6 \nabla$ & $26,4 \nabla$ & $29,0 \Delta$ & $26,9 \nabla$ & $26,7 \nabla$ \\
\hline 6 & Avusturalya & 6,2 & $7,1 \Delta$ & $7,7 \Delta$ & $8,2 \Delta$ & $9,0 \Delta$ & $9,4 \Delta$ & $9,8 \Delta$ & $10,3 \Delta$ & $10,9 \mathbf{\Delta}$ & $11,4 \Delta$ & $11,7^{*} \Delta$ \\
\hline 7 & Kanada & 26,2 & $28,6 \Delta$ & $30,4 \Delta$ & 32,2 A & $32,9 \Delta$ & $33,5 \Delta$ & $32,2 \nabla$ & $31,2 \nabla$ & $33,0 \Delta$ & $26,0 \nabla$ & $26,5 \Delta$ \\
\hline 8 & Rusya & 34,2 & $39,3 \Delta$ & $43,7 \Delta$ & $47,8 \Delta$ & $54,0 \Delta$ & $45,8 \nabla$ & $34,5 \nabla$ & $31,6 \nabla$ & $39,6 \Delta$ & $41,9 \Delta$ & $48,0 \Delta$ \\
\hline 9 & Kore C. & 9,4 & $12,4 \Delta$ & $12,6 \Delta$ & $13,7 \triangle$ & $14,8 \wedge$ & $16,0 \Delta$ & $19,3 \Lambda$ & 22,34 & $26,4 \Delta$ & $28,6 \wedge$ & $28,7 \triangle$ \\
\hline \multirow[t]{2}{*}{10} & İtalya & 27,4 & $28,1 \Delta$ & $27,8 \nabla$ & $27,3 \nabla$ & $26,3 \nabla$ & $26,8 \Delta$ & $27,4 \Delta$ & $29,0 \Delta$ & $31,8 \Delta$ & $33,3 \wedge$ & $34,8^{*} \Delta$ \\
\hline & $\begin{array}{l}\text { Hong Kong } \\
\text { (Çin) }\end{array}$ & 81,9 & $84,4 \Delta$ & $84,8 \wedge$ & $85,2 \wedge$ & $84,4 \nabla$ & $84,5 \wedge$ & $89,0 \triangle$ & $91,7 \triangle$ & $91,3 \nabla$ & $92,2 \Delta$ & $93,1^{*} \Delta$ \\
\hline$\ldots$ & Türkiye & 5,5 & $6,5 \Delta$ & $6,2 \nabla$ & $5,8 \nabla$ & $7,5 \Delta$ & $7,9 \triangle$ & $8,7 \triangle$ & $7,8 \nabla$ & $8,8 \triangle$ & $8,3 \nabla$ & $9,6 \triangle$ \\
\hline
\end{tabular}

Kaynak: www.unwto.org, www.data.worldbank.org, www.store.globaldata.com, www.ceicdata.com, www.export.gov, www.prnewswire.com, www.destinationnsw.com.au, www.russtd.com, www.ustravel.org, www.kto.visitkorea.or.kr, www150.statcan.gc.ca * 2019 yll beklentileridir.

$\Delta$ : Bir önceki yıl ile kıyaslandı̆̆ında artış, $\quad \nabla$ : Bir önceki yıl ile kıyaslandı̆̆ında azalış

Tablo 2 incelendiğinde, son on bir yıldaki (2009-2019) uluslararası turizme katılımın genel bir artış halinde olduğu görülmektedir. Birleşmiş Milletler Dünya Turizm Örgütü'nün verileri de elde edilen bu artışı doğrulamaktadır. Diğer bir ifadeyle, 2019 yılında uluslararası seyahat eden turist sayısının 1,5 milyara ulaştığı belirtilmektedir. Uluslararası turizm harcamalarına paralel olarak, özellikle 2013 ve 2017 yıllarında tüm ülkeler düzeyinde (Hong Kong (Çin) ve İtalya hariç) bir artış görülmektedir. Kısmi azalmalar yaşansa da genel anlamda uluslararası turizme katılanların sayısında 2009-2019 yılları arasında bir artış yaşanmıştır. Sınırlılık kapsamında tabloda yer almayan fakat incelenmesi gereken başka bir durum da uluslararası turizm harcamalarına paralel olarak 2009 yılında yaşanmıştır. 2009 yılı verileri bir önceki yıl ile karşılaştıııldığında, 2009 yılındaki uluslararası turizme katılanların sayısında Çin, Avusturalya, Türkiye ve İtalya hariç azalma görülmektedir. Benzer bir biçimde, 2008 yılındaki küresel ekonomik krizin, uluslararası turizme katılanların sayısını azalttığı ifade edilebilir.

Son on bir yılın (2009-2019) verileri dikkate alındığında, sadece Çin ve Avusturalya'daki uluslararası turizme katılanların sayısında herhangi bir düşüş yaşanmadığı tespit edilmiştir. 
Diğer ülkelerde ise belli dönemlerde azalmalar yaşanmıştır. Uluslararası turizme katılım bakımından 2019 yılı verilerine göre Çin, 169,2 milyon kişi ile ilk sırada yer almaktadır. Çin'i, 110,6 milyon kişi ile Almanya, 93,1 milyon kişi ile Hong Kong (Çin), 83,4 milyon kişi ile ABD takip etmektedir. Bununla birlikte, Almanya, Avustralya, İtalya ve Hong Kong (Çin)'a ait tablodaki 2019 yılı verileri, 2019 yılı beklenti rakamlarını ifade etmektedir. Uluslararası turizm harcamalarına paralel olarak, uluslararası turizme katılım noktasında da Çin, lider ülke konumundadır. Ortaya çıkan tablo Çin'in, turizm sektöründeki en önemli pazarlardan birisini oluşturduğunu göstermektedir.

Türkiye'ye bakıldığında ise, uluslararası turizme katılma noktasında, son on bir yılda istikrarlı bir artış yakalayamasa da genel olarak bir artış yaşandığı belirlenmiştir. Türkiye' de 2009 yılında uluslararası turizme katılım 5,5 milyon iken, 2019 yılında 9,6 milyona yükselmiştir. Sonuçlar, Türkiye'nin uluslararası turizme katılan kişi sayısında kademeli bir artış yaşadığını ortaya koymaktadır. Turizm harcamalarında yaşanan olumsuz tablonun, turizme katılanların sayısında yaşanmadığı görülmektedir. Ortaya çıkan sonuçlar, yurtdışına tatile giden Türk vatandaşlarının sayısının arttığını ortaya koymaktadır. Fakat 2011-2012 yıllarında, yurtdışına çıkan Türk vatandaşlarının sayısında önemli bir azalma meydana gelmiştir. Bu azalmanın temelinde ise, 2008-2012 yılları arasında genel olarak dünyada kendisini hissettiren ekonomik bunalım yer almaktadır. Bunun dışında birtakım sosyal ve politik krizlerde ziyaretçi sayılarını etkilemiştir. Bununla birlikte Tablo 1 ve Tablo 2 karşılaştırıldığında dünyadaki krizlerin, uluslararası turizme katılanların sayısından ziyade uluslararası turizm harcamaları noktasında kendisini daha fazla hissettirmiştir. Uluslararası turizme katılanların oranında kısmen düşüşler yaşansa da son on bir yılda genel bir artış eğiliminden bahsetmek mümkündür. Ayrıca, 2020 yılında tüm dünyayı etkisi altına alan Covid-19 salgınının, uluslararası turizm harcamalarına paralel olarak 2020 yılından itibaren tüm ülkelerin uluslararası turizme katılan sayısını da olumsuz etkileyeceği öngörülmektedir. 2020 yılından itibaren uluslararası turizme katılan sayıları takip edilerek, salgının etki boyutu incelenmelidir. Özellikle dünya genelinde seyahat kısıtlarının yaşanması, ekonomilerin sağlık alanına kayması göstergeleri olumsuz etkileyecektir. En fazla uluslararası turizm harcaması yapan ülkeler ve Türkiye' nin 2019 yılına ait nüfus, GSYH ve kişi başına düşen GSYH bilgileri ise Tablo 3'te yer almaktadır.

Tablo 3. Nüfus, GSYH ve Kişi Başına Düşen GSYH Bilgileri (2019)

\begin{tabular}{|c|c|c|c|c|}
\hline$\stackrel{5}{\omega}$ & ülkeler & $\begin{array}{l}\text { Nüfus } \\
\text { (Milyon) }\end{array}$ & $\begin{array}{c}\text { GSYH } \\
\text { (Milyar \$) }\end{array}$ & $\begin{array}{c}\text { Kişi Başına Düşen } \\
\text { GSYH (\$) }\end{array}$ \\
\hline 1 & Çin & $1,400,2$ & 14,140 & 10,099 \\
\hline 2 & ABD & 329,3 & 21,439 & 65,112 \\
\hline 3 & Almanya & 83,0 & 3,863 & 46,564 \\
\hline 4 & Birleşik Krallık & 66,9 & 2,744 & 41,030 \\
\hline 5 & Fransa & 64,8 & 2,707 & 41,761 \\
\hline 6 & Kanada & 37,5 & 1,731 & 46,213 \\
\hline 7 & Kore Cumhuriyeti & 51,8 & 1,630 & 31,431 \\
\hline 8 & Avustralya & 25,2 & 1,450 & 55,305 \\
\hline 9 & İtalya & 60,4 & 1,989 & 32,947 \\
\hline 10 & Hong Kong (Çin) & 7,4 & 365,1 & 48,760 \\
\hline 11 & Türkiye & 83,0 & 744 & 8,958 \\
\hline
\end{tabular}


Tablo 3'te yer alan ülkelerin 2019 yılına ait verileri incelendiğinde, Çin ve ABD'nin nüfusunun diğer ülkelerin kat kat fazlasını oluşturduğu açıktır. İlgili ülkelerin GSYH miktarlarına bakıldığında da $\mathrm{ABD}$ ve Çin'in en yüksek miktarlara sahip olduğu görülmektedir. Fakat kişi başına düşen GSYH verileri, ABD (65,112 \$) ile Avustralya'nın (55,305 \$) en yüksek değerlere sahip ülkeler olduğunu göstermektedir. Çin, GSYH miktarı olarak, ABD'den sonra ikinci sırada yer almasına rağmen, kişi başına düssen GSYH miktarı Türkiye'den sonra en az olan ülke konumundadır. Kişi başına düşen GSYH miktarı bakımından öne çıkan ülkeler sırasıyla, ABD, Avustralya, Hong Kong (Çin), Almanya ve Kanada'dır. Türkiye'nin sahip olduğu kişi başına düşen GSYH miktarı (8,958 \$) en fazla uluslararası turizm harcaması yapan ülkeler ile kıyaslandığında, en düşük miktara sahiptir. Türkiye'de, son on bir yılda (2009-2019) küçük hareketlenmeler yaşanmakla birlikte, durağan bir durum olduğu söylenebilir. Sonuçlar, özellikle $A B D$ ve Çin'in son on bir yılda kademeli bir artış yaşadığını ortaya koymaktadır.

Tablo 3'te yer alan ülkeler ile kıyaslama yapıldığında Türkiye'nin, en düşük GSYH'ye (Hong Kong (Çin) hariç) ve kişi başına düşen GSYH'ye sahip olduğu görülmektedir. Türkiye, 2019 yılı içerisinde özellikle Ağustos 2018'den itibaren etkisini güçlü bir şekilde hissettiren döviz kuru krizi ile mücadele etmektedir. Bu kriz özellikle enflasyon ve faizleri yükselterek, ekonominin küçülmesine neden olmuştur. Ayrıca Orta Doğu'da yaşanan krizler, küresel ölçekte güven ortamının azalması beraberinde işsizlik oranlarını da arttırmıştır. İlk etapta kendisini ekonomik olarak hissettiren kriz devamında sosyal krizi de tetiklemiştir. Türkiye'de 2013 yılında 12,480 dolara kadar çıkan kişi başı gelir 2019 yılı sonunda 8,958'e kadar gerilemiştir.

Seyahat ve Turizm Rekabet Edebilirlik Raporu, sektörlerdeki eğilimlerin analizi ile küresel bir yaklaşım izlemektedir. Uzun vadeli seyahat ve turizm rekabetçiliğini sağlamak için uluslararası kuruluşlar ve hükümetten küresel liderlerin kritik konulara karşı yaklaşımlarını sunmaktadır. Seyahat ve Turizm Rekabet Edebilirlik Endeksi, "bir ülkenin kalkınmasına ve rekabetçiliğine katkıda bulunan seyahat ve turizm sektörünün sürdürülebilir kalkınmasını sağlayan faktörler ve politikalar setini" ölçmektedir. Endeks, 140 ekonominin 90 bireysel göstergesi, 14 sütun ve 4 alt endeksten meydana gelmektedir. Tablo 4'te ülkelerin Seyahat ve Turizm Rekabet Edebilirlik Endeksi (2019)'ne ait göstergeleri ve sıralamaları yer almaktadır.

Tablo 4'te yer alan, ülkelerin Seyahat ve Turizm Rekabet Edebilirlik Endeksi (2019)'ne ait genel puanları incelendiğinde sırasıyla, İspanya (5,4 puan), Fransa (5,4 puan), Almanya (5,4) ve Japonya'nın $(5,4)$ ilk dört sırada yer aldıkları görülmektedir. Birleşmiş Milletler Dünya Turizm Örgütü'nün 2018 yılı verilerine göre, dünyada en fazla ziyaretçi çeken ilk iki ülke sırasıyla Fransa (89,4 milyon kişi) ve İspanya (82,8 milyon kişi) olmuştur (UNWTO, 2020). Tablo 4 'te yer alan endeks sonuçları ile ziyaretçi sayıları karşılaştırıldığında paralellik bulunmaktadır. İspanya'nın endekste en iyi olduğu alanlar, turist hizmet altyapısı (3. sıra) ve kültürel kaynaklar ve iş seyahatidir (3. sıra). Bununla birlikte, seyahat ve turizm önceliği alanında da 8. sırada yer almaktadır. Fransa ise, kültürel kaynaklar ve iş seyahati (2. sıra) ile yer ve liman altyapısı (7. sıra) alanları ile ön plana çıkmaktadır. Endeks verilerine göre Türkiye, genel sıralamada 43. sıradadır (4,2 puan). Türkiye'nin en iyi olduğu alanlar ise, hava taşımacılı̆̆ı altyapısı (20. sıra) ile kültürel kaynaklar ve iş seyahati (17. sıra) alanlarıdır. Turist hizmet altyapısı gibi önemli bir alanda ise 37. sıradadır. Elde edilen sonuçlar, Türkiye'nin turist hizmet altyapısı, sağlık ve hijyen gibi alanlarda çalışmalar yapmasını gerekli kılmaktadır. Rapor sonuçlarına göre; sağlık ve hijyen alanında Avusturya, hava taşımacılığı altyapısında Kanada, çevresel sürdürülebilirlik alanında İsviçre, iş çevresi, bilgi iletişim teknolojilerine hazırlık ile yer ve liman altyapısı alanlarında Hong Kong (Çin), kültürel kaynaklar ve iş seyahati alanında da Çin ilk sırada yer almaktadır. Endeksteki sütunlara yönelik, Türkiye'nin diğer ülkelere kıyasla detaylı puan ve sıralaması Tablo 5'te yer almaktadır. 
Tablo 4: Ülkelerin Seyahat ve Turizm Rekabet Edebilirlik Endeksi Göstergeleri ve Siralamaları (2019)

\begin{tabular}{|c|c|c|c|c|c|c|}
\hline \multirow{3}{*}{$\frac{5}{5}$} & \multirow{3}{*}{$\begin{array}{c}\text { Ülkeler } \\
\text { İspanya }\end{array}$} & $\begin{array}{c}\text { Siralamal } \\
\text { Endeks }\end{array}$ & \multicolumn{3}{|c|}{ Ülkelerin En İyi Sütun Dereceleri } & \multirow{3}{*}{ 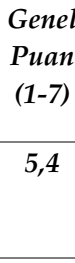 } \\
\hline & & Siralama & $3^{r d}$ & $3^{r d}$ & $8^{\text {th }}$ & \\
\hline & & Endeks & $\begin{array}{c}\text { Turist Hizmet } \\
\text { Altyapıs1 }\end{array}$ & $\begin{array}{c}\text { Kültürel Kaynaklar ve } \\
\text { İş Seyahati }\end{array}$ & $\begin{array}{c}\text { Seyahat ve Turizm } \\
\text { Önceliği }\end{array}$ & \\
\hline \multirow[t]{2}{*}{2} & \multirow[t]{2}{*}{ Fransa } & Siralama & $2^{\text {nd }}$ & $7^{\text {th }}$ & $17^{\text {th }}$ & \multirow[t]{2}{*}{5,4} \\
\hline & & Endeks & $\begin{array}{c}\text { Kültürel Kaynaklar } \\
\text { ve İş Seyahati }\end{array}$ & $\begin{array}{l}\text { Yer ve Liman } \\
\text { Altyapısı }\end{array}$ & $\begin{array}{c}\text { Doğal Kaynaklar \& } \\
\text { Hava Taşımacılığı } \\
\text { Altyapısı }\end{array}$ & \\
\hline \multirow[t]{2}{*}{3} & \multirow[t]{2}{*}{ Almanya } & Siralama & $2^{\text {nd }}$ & $6^{\text {th }}$ & $6^{\text {th }}$ & \multirow[t]{2}{*}{5,4} \\
\hline & & Endeks & Sağlık ve Hijyen & $\begin{array}{c}\text { Yer ve Liman } \\
\text { Altyapısı }\end{array}$ & $\begin{array}{c}\text { Kültürel Kaynaklar } \\
\text { ve İş Seyahati }\end{array}$ & \\
\hline \multirow[t]{2}{*}{4} & \multirow[t]{2}{*}{ Japonya } & Siralama & $5^{\text {th }}$ & $6^{\text {th }}$ & $10^{\text {th }}$ & \multirow[t]{2}{*}{5,4} \\
\hline & & Endeks & $\begin{array}{c}\text { Kültürel Kaynaklar } \\
\text { ve İş Seyahati }\end{array}$ & Uluslararası Açıklık & BİT Hazırlık & \\
\hline \multirow[t]{2}{*}{6} & \multirow{2}{*}{$\begin{array}{l}\text { Birleşik } \\
\text { Krallık }\end{array}$} & Siralama & $6^{\text {th }}$ & $9^{\text {th }}$ & $7^{\text {th }}$ & \multirow[t]{2}{*}{5,2} \\
\hline & & Endeks & İş Çevresi & $\begin{array}{c}\text { Hava Taşımacılı̆̆ı } \\
\text { Altyapısı }\end{array}$ & $\begin{array}{c}\text { Turist Hizmet } \\
\text { Altyapısı }\end{array}$ & \\
\hline \multirow[t]{2}{*}{5} & \multirow[t]{2}{*}{$A B D$} & Siralama & $1^{\text {st }}$ & $3^{r d}$ & $4^{\text {th }}$ & \multirow[t]{2}{*}{5,3} \\
\hline & & Endeks & $\begin{array}{c}\text { İnsan Kaynakları ve } \\
\text { İş Piyasası }\end{array}$ & $\begin{array}{c}\text { Hava Taşımacılığ } \\
\text { Altyapısı }\end{array}$ & $\begin{array}{c}\text { Turist Hizmet } \\
\text { Altyapısı }\end{array}$ & \\
\hline \multirow[t]{2}{*}{7} & \multirow[t]{2}{*}{ Avustralya } & Siralama & $2^{\text {nd }}$ & $2^{\text {nd }}$ & $3^{r d}$ & \multirow[t]{2}{*}{5,1} \\
\hline & & Endeks & Uluslararası Açıklık & $\begin{array}{c}\text { Hava Taşımacılığ } 1 \\
\text { Altyapısı }\end{array}$ & Doğal Kaynaklar & \\
\hline \multirow[t]{2}{*}{8} & \multirow[t]{2}{*}{ Italya } & Siralama & $4^{\text {th }}$ & $10^{\text {th }}$ & $7^{\text {th }}$ & \multirow[t]{2}{*}{5,1} \\
\hline & & Endeks & $\begin{array}{c}\text { Kültürel Kaynaklar } \\
\text { ve İş Seyahati }\end{array}$ & $\begin{array}{c}\text { Turist Hizmet } \\
\text { Altyap1s1 }\end{array}$ & Doğal Kaynaklar & \\
\hline \multirow[t]{2}{*}{9} & \multirow[t]{2}{*}{ Kanada } & Siralama & $1^{\text {st }}$ & $8^{\text {th }}$ & $11^{\text {th }}$ & \multirow[t]{2}{*}{5,1} \\
\hline & & Endeks & $\begin{array}{c}\text { Hava Taşımacılığı } \\
\text { Altyapısı }\end{array}$ & $\begin{array}{c}\text { Turist Hizmet } \\
\text { Altyapıs1 }\end{array}$ & Doğal Kaynaklar & \\
\hline \multirow[t]{2}{*}{10} & \multirow[t]{2}{*}{ Isviçre } & Siralama & $1^{s t}$ & $2^{\text {nd }}$ & $3^{r d}$ & \multirow[t]{2}{*}{5,0} \\
\hline & & Endeks & $\begin{array}{c}\text { Çevresel } \\
\text { Sürdürülebilirlik }\end{array}$ & $\begin{array}{c}\text { İnsan Kaynakları ve İş } \\
\text { Piyasası }\end{array}$ & İş Çevresi & \\
\hline 14 & Hong Kong & Siralama & $1^{s t}$ & $1^{s t}$ & $1^{\text {st }}$ & 4,8 \\
\hline & (Çin) & Endeks & İş Çevresi & BİT Hazırlık & $\begin{array}{c}\text { Yer ve Liman } \\
\text { Altyapısı }\end{array}$ & \\
\hline 13 & Çin & Siralama & $1^{s t}$ & $4^{\text {th }}$ & $24^{\text {th }}$ & 4,9 \\
\hline & & Endeks & $\begin{array}{c}\text { Kültürel Kaynaklar } \\
\text { ve İş Seyahati }\end{array}$ & Doğal Kaynaklar & $\begin{array}{c}\text { İnsan Kaynakları ve } \\
\text { İş Piyasası }\end{array}$ & \\
\hline 16 & Kore & Siralama & $7^{\text {th }}$ & $11^{\text {th }}$ & $17^{\text {th }}$ & 4,8 \\
\hline & Cumhuriyeti & Endeks & BİT Hazırlık & $\begin{array}{c}\text { Kültürel Kaynaklar ve } \\
\text { İş Seyahati }\end{array}$ & Uluslararası Açıklık & \\
\hline 43 & Türkiye & Siralama & $20^{\text {th }}$ & $17^{\text {th }}$ & $37^{n d}$ & 4,2 \\
\hline & & Endeks & $\begin{array}{c}\text { Hava Taşımacılığı } \\
\text { Altyapısı }\end{array}$ & $\begin{array}{c}\text { Kültürel Kaynaklar ve } \\
\text { İş Seyahati }\end{array}$ & $\begin{array}{c}\text { Turist Hizmet } \\
\text { Altyapısı }\end{array}$ & \\
\hline
\end{tabular}

Kaynak: www.weforum.org

Endeks sonuçları Avrupa bölgesini, sahip olduğu kültürel kaynaklar ve neredeyse tüm sütunlardaki liderlik konumundan dolayı en rekabetçi seyahat ve turizm bölgesi olarak kabul etmektedir. Türkiye'nin de Avrupa bölgesinde ve Akdeniz çanağında bir ülke olması, diğer Avrupa ülkeleri ile rekabet etmesini gerekli kılmaktadır. Burada tüm ülkelerin ortak gayesi, turizm gelirlerinden en fazla payı alabilmektir. Bu nedenle Türkiye, dünyada ve diğer Avrupa 
bölgelerinde yaşanan gelişmeleri yakından takip etmek durumundadır. Örneğin endekse göre Avrupa bölgesindeki en önemli gelişmeler, bilgi ve iletişim teknolojilerine hazırlık, fiyat rekabet gücü ve hava taşımacılığı altyapısında gerçekleşmektedir. Sonuçlar, Türkiye'nin ivedilikle bilgi ve iletişim teknolojilerine yönelmesini gerekli kılmaktadır. Diğer Avrupa ülkeleri ile kıyaslandığında, özellikle düşük puana sahip olduğu güvenlik, çevresel sürdürülebilirlik ve iş gücü noktalarında adımlar atmalıdır. Özellikle güvenlik, turistler için destinasyon tercih nedeni olabilmektedir. Örneğin Silik ve Ünlüönen (2018) tarafından Türkiye'deki kayak merkezlerine yönelik yapılan çalışmada, ziyaretçilerin kayak merkezlerindeki güvenlik önlemlerini yetersiz bulduğu tespit edilmiştir. Bu sonuçlar, güvenlik noktasında her işletmenin kendi tedbirlerini azami düzeyde almasını gerekli kılmaktadır. Seyahat ve Turizm Rekabet Edebilirlik Endeksi'nin 2019 yılı raporunda, Türkiye'nin toplam 14 sütuna ait puanları ve ülkeler arasındaki sıralaması Tablo 5'te yer almaktadır. Tablo 5'te, Türkiye'nin endekste yer alan toplam 140 ülke arasındaki sıralaması alanlar bazında belirtilmiştir.

Tablo 5: Türkiye'nin Seyahat ve Turizm Rekabet Edebilirlik Endeksi Puan ve Siralaması (2019)

\begin{tabular}{clc}
\hline $\begin{array}{c}\text { Siralama } \\
\text { (140 ülke arasindan) }\end{array}$ & \multicolumn{1}{c}{ Sütunlar (14 tane) } & $\begin{array}{c}\text { Puan } \\
\mathbf{( 1 - 7 )}\end{array}$ \\
\hline 20 & Hava Taşımacıllŏı Altyapısı & 4,7 \\
\hline 17 & Kültürel Kaynaklar ve İş Seyahati & 3,8 \\
\hline 37 & Turist Hizmet Altyapisı & 5,0 \\
\hline 52 & Uluslararası Açılık & 3,8 \\
\hline 56 & Yer ve Liman Altyapısı & 3,6 \\
\hline 71 & İş Çevresi & 4,4 \\
\hline 65 & Sağlık ve Hijyen & 5,5 \\
\hline 77 & Doğal Kaynaklar & 2,8 \\
\hline 48 & Fiyat Rekabeti & 5,6 \\
\hline 71 & BİT Hazırlık & 4,6 \\
\hline 39 & Seyahat ve Turizm Önceliği & 5,1 \\
\hline 97 & İnsan Kaynakları ve İş Piyasası & 4,2 \\
\hline 126 & Çevresel Sürdürülebilirlik & 3,7 \\
\hline 125 & Emniyet ve Güvenlik & 4,3 \\
\hline
\end{tabular}

Kaynak: www.weforum.org

Tablo 5'te yer alan veriler incelendiğinde, Türkiye'nin seyahat ve rekabet edebilirlik endeksindeki alanlar arasında sahip olduğu en iyi sıralama "hava taşımacıllğı alt yapısına" (20. sıra) ait iken, en kötü sıralaması da "çeoresel sürdürülebilirlik" (126) ve "emniyet ve güvenlik" (125) alanlarına aittir. Buradan hareketle, Türkiye'ye gelecek ziyaretçilerde, emniyet ve güvenlik ile ilgili kaygıların yaşandığı ve çevreye gerekli hassasiyetin verilmediği söylenebilir. Turistlerin destinasyon tercihlerini etkileyen en önemli faktörlerden birisi emniyet ve güvenlik konusudur. Böyle bir durumda Türkiye'nin, sıralamasının gerilerde olması ziyaretçi sayısını da olumsuz etkileyebilecektir. Elde edilen sonuçlar Türkiye'nin, ivedilikle emniyet ve güvenlik ile çevresel sürdürülebilirlik sorunlarına ağırlık vermesini gerekli kılmaktadır.

Son olarak, en fazla uluslararası turizm harcaması yapan ülkelerin (Tablo 1); enflasyon oranı, işsizlik oranı, çalışma saatleri, harcanabilir gelir, eğitim durumu ve yaşam memnuniyetleri incelenmiştir. İnceleme sonucunda elde edilen veriler, aşağıda belirtilen başlıklar altında kısaca ifade edilmiştir. 
Enflasyon Oranı: En fazla uluslararası turizm harcaması yapan ülkelerin enflasyon oranları ile Türkiye mukayese edildiğinde arada önemli farkların olduğu görülmektedir. Uluslararası Para Fonu'na (IMF) göre, Türkiye' deki 2019 yıllık enflasyon rakamı \% 15,7'dir. Bununla birlikte diğer ülkelerin 2019 yılı enflasyon rakamlarına bakıldığında (yüzdelik oranlar), ABD 1,8, Çin 2,3, Almanya 1,5, Birleşik Krallık 1,8, Fransa 1,2, Kanada 2,0, İtalya 0,7, Güney Kore 0,5 ve Rusya 4,7'dir (EBSO, 2020).

Gelişmiş ülkelerdeki \% 2-3 oranlarındaki enflasyon ile Türkiye gibi gelişmekte olan ülkelerin enflasyon oranlarını bir arada değerlendirmek çok sağlıklı sonuçlar vermeyecektir. Bu nedenle enflasyon olgusunu gelişmiş ve gelişmekte olan ülkeler için ayrı ayrı ele almak daha doğru olacaktır. Enflasyon oranları bakımından en başarısız ülkenin \% 54,4 enflasyon oranı ile Arjantin olduğunu belirtmek gerekmektedir. Arjantin'in kriz ortamında olduğu düşünüldüğünde, Türkiye'nin diğer ülkelere göre enflasyon durumunun oldukça kötü bir durumda olduğu görülebilmektedir.

Uluslararası turizm alanında rekabet edebilmek için ekonomik güç sahibi olmak gerekmektedir. Sadece ekonomik güce sahip olmak başlı başına bir etken olmamakla birlikte önemli bir değişkendir. Çünkü enflasyonun düşük olması vatandaşların satın alma gücünü arttırmaktadır. Satın alma gücü artan vatandaşların da seyahat ve turizm gibi harcamalar için ayıracakları miktarlar artacaktır. Domino etkisi oluşturacak olan bu ekonomik güç, uluslararası turizme katılan kişi sayılarını doğrudan etkileyecektir. Bu nedenle ekonominin temel göstergelerinden birisi olan enflasyon, ülkeleri gerek uluslararası turizm harcamaları gerekse de uluslararası turizme katılım noktasında etkilemektedir.

İşsizlik Oranı: Bu oran, Fransa ve İtalya hariç, en fazla uluslararası turizm harcaması yapan ülkeler arasında \% 3,5 ile \% 6 arasında değişmektedir. Uluslararası Para Fonu'nun (IMF) tahmini verilerine göre, Türkiye'deki 2019 yılı tahmini işsizlik oranı \% 13,8'dir. Bununla birlikte diğer ülkelerin 2019 yılı tahmini işsizlik oranlarına bakıldığında (yüzdelik oranlar), ABD 3,7, Çin 3,8, Almanya 3,2, Birleşik Krallık 3,8, Fransa 8,6, Kanada 5,8, İtalya 10,3, Güney Kore 4,0 ve Rusya $4,6^{\prime}$ dır (EBSO, 2020). İlgili ülkelerin işsizlik oranları incelendiğinde, Türkiye ve İtalya'nın en fazla işsizlik oranına sahip olduğu görülmektedir.

İşsizlik, küresel krizler ile birlikte dünya genelinde artmaya devam eden bir sorundur. Özellikle Türkiye gibi gelişmekte olan ülkelerin istihdamı arttıracak yatırımlara yönelmesi gerekmektedir. Çünkü 2019 yılı verileri, Türkiye'nin işsizlik oranı en fazla artan ülkelerden birisi olduğunu göstermektedir. Turizm sektörünün istihdama olan katkısı, ülkeler için göz ardı edilemez boyuttadır. Dünya Seyahat ve Turizm Konseyi'nin verilerine göre, turizm 2019 yılında 330 milyon istihdam sağlamıştır. Veriler, dünyadaki her 10 kişiden birinin turizm sektöründe çalıştığını göstermektedir. Ayrıca Covid-19 salgını nedeniyle, 2020 yılında işsizlik oranlarının daha da artacağı öngörülmektedir. Salgın nedeniyle, turizm işletmelerinde çalışan birçok kişinin iş akdine son verilmiştir. Böylesi bir durumda, istihdama katkısı bakımından da turizmin korunması gereken sektörlerden birisi olduğu söylenebilir.

Çalışma Saatleri: En fazla uluslararası turizm harcaması yapan ülkeler arasında en fazla çalışma saatlerine sahip ülkeler Kore (haftalık 52 saat) ve Türkiye (haftalık 48,9 saat)'dir. Diğer ülkeler, Kore ve Türkiye' den daha az çalışma saatlerine sahiptir. Ekonomik İşbirliği ve Kalkınma Örgütü verilerine göre, Türkiye en fazla çalışma süresine sahip 14. ülkedir. Turizm sektörü gibi hizmet sektöründe çalışma saatlerinin gereğinden fazla olması hizmet kalitesi açısından da önem arz etmektedir. Çalışma sürelerinin özellikle hizmet sektöründe makul tutulması hizmet kalitesini doğrudan etkileyecektir. Türkiye'de haftalık çalışma saatleri, 4857 sayılı İş Kanunu'nun 63. Maddesi ile düzenlenmiştir. Buna göre, haftalık çalışma süresi en fazla 45 saat olarak belirlenmiştir. 
Çalışma saatleri konusunda önemli olan bir başka nokta da verimliliktir. Çalışma saatinden ziyade verimli çalışmak da önemlidir. Thomas More'nin ütopyasında (Ütopya adlı eserinde), günlük çalışma saatlerinin düşürülmesinin çalışanlar için en iyisi olacağ çalışma süresi olarak günlük 6 saatin yeterli olacağı savunulmaktadır. Bununla birlikte çalışma sürelerinin yapılan işe göre de farklılık gösterebileceği de başka bir tartışma konusudur. Turizm sektörü özelinde değerlendirme yapılacak olursa, günlük çalışma sürelerinin 8 saatten fazla olması verimliliği ve etkinliği azaltacaktır.

Turizm sektöründe müşteri memnuniyeti sağlamanın ön koşullarından birisi de hizmet kalitesinin yüksek olmasıdır. Müşteri memnuniyeti yüksek olan kişilerde sadakatin de oluşması kolaylaşmaktadır. Turizm sektöründe sadakatin oluşması ise turizm işletmelerine olan talebi arttırmaktadır. Görüleceği üzerine hizmet sektöründe atılan her adım bir diğerini etkilemektedir. $\mathrm{Bu}$ nedenle çalışma sürelerinin yüksek olması çalışanların verimini azaltacak, beraberinde de hizmet kalitesini düşürecektir. Özellikle turizm sektöründe müşterilere iyi bir hizmet sağlayabilmek için uygun çalışma saatlerine ihtiyaç duyulmaktadır.

Eğitim Durumu: Ekonomik İşbirliği ve Kalkınma Örgütü 2019 verilerine göre, yüksek lisans eğitim düzeyine sahip yetişkin oranı OECD ülkelerinde ortalama \% 14,3 iken, Türkiye' de bu oran 2,6'dır. Ortaya çıkan göstergeler, Türkiye' deki eğitim durumunun diğer ülkelere kıyasla geride kaldığını göstermektedir. Dünya Ekonomik Forumu tarafından yayınlanan "Eğitim Kalitesi 2018" isimli rapora göre Türkiye, 137 ülke arasından 99. sırada yer almaktadır. Listenin 1. sırasında İsviçre, ardından Singapur, Finlandiya ve Hollanda gelmektedir. Singapur, toplam bütçesinin \% 30 'unu eğitime harcamaktadır. Türkiye'de ise bu oran daha düşük düzeydedir. Milli Eğitim Bakanlığı'nın merkezi yönetim bütçesi 2019 yılında \% 11,84'tür. Eğitim alanında diğer ülkeleri yakalayabilmek için ayrılan bütçenin arttırılması gerekliliği ortaya çıkmaktadır.

OECD verilerine göre, Türkiye'deki yükseköğretim öğrencilerinin büyük bir kısmı ortalamanın altında istihdam olanağına sahip olmasına rağmen işletme ve hukuk okumaktadır. Bununla birlikte, Türkiye'de çok az sayıda genç erken çocukluk eğitimi okumaktadır. Verilere göre Türkiye, kamu ve özel kurumlardaki öğrenme ortamları arasında en büyük farka sahip ülkelerden birisidir. Türkiye'nin küresel ölçekte bilinen teknolojik bir ürününün, markasının olmaması eğitim sisteminde yaşanan tartışmaları ortaya çıkarmaktadır. Diğer ülkeler ile karşılaştırma yapıldığında, ezbere dayalı bir yapının hâkim olması, sorgulayan, eleştiren bir yapının oluşmaması eğitimde mevcut olan temel sorunlar olarak görülmektedir. Ayrıca Türkiye'deki okuma alışkanlıklarının diğer ülkelere kıyasla daha düşük olması ülkenin eğitim durumunu olumsuz etkilemektedir. Turizm eğitimi kapsamında değerlendirme yapıldığında ise, Türkiye'deki eğitim kurumları ile işletmeler arasındaki iletişim (erişim) problemi başlıca sorunlardan birisidir. Türkiye'de turizm eğitimi alan öğrencilerin sektörden uzak kaldıkları görülmektedir. Türkiye' de önceki dönemlerde mevcut olan turizm meslek liselerinin kapatılması da sektöre kalifiye personel yetiştirilmesini olumsuz yönde etkilemiştir.

Sosyal, kültürel ve ekonomik göstergeler kapsamında, en fazla turizm harcamasına sahip ülkeler ile Türkiye arasında karşılaştırma yapıldığında, Türkiye'deki işsizlik oranının çok yüksek olduğu, eğitim durumunun çok geride olduğu ve çalışma saatlerinin yüksek olduğu belirlenmiştir. Ayrıca Türkiye' deki seyahat ve turizm harcamalarına yönelik ayrılan bütçenin de yüzdelik olarak diğer ülkelerin çok gerisinde kaldığı görülmektedir. Elde edilen sonuçlar, Türkiye'nin sosyal, kültürel ve ekonomik alanda yatırımlar yapması gerekliliğini ortaya koymaktadır. 


\section{TARTIŞMA, SONUÇ ve ÖNERİLER}

Turizm harcamaları, turizmin yerel ekonomi üzerindeki etkisini izlemek ve değerlendirmek için politika yapıcılar, planlama yetkilileri, pazarlamacılar ve araştırmacılar tarafından incelenmektedir (Wang vd., 2006). Turizme uygulanan tüketici talep teorisi, turizm talebinin miktarının nüfus, gelir, fiyatlar, tüketicilerin zevki, pazarlama ve diğer sosyal, kültürel, coğrafi ve politik faktörlerle yakından ilgili olduğunu göstermektedir (Witt ve Witt, 1995). Bu çalışmada, makro düzeyde, sosyal, kültürel ve ekonomik yaklaşımla uluslararası turizm harcamalarının kapsamlı ve dikkat çekici bir görünümü ortaya konulmaya çalışılmıştır.

Çalışma sonuçları, uluslararası turizm harcamaları ve uluslararası turizme katılım oranları ile ilgili Çin'in yükselen değerini ortaya koymaktadır. Gerek uluslararası turizm harcamaları gerekse de uluslararası turizme katılım noktasında Çin, diğer ülkelere kıyasla ciddi oranda öndedir. Veriler, ilerleyen dönemlerde ülkelerin Çin pazarına ağırlık verebileceğini göstermektedir. Bu nedenle, turizm sektörüne yönelik atılacak adımlarda Çin'in yükselen trendi göz önüne alınmalıdır.

Türkiye'ye ait veriler incelendiğinde, 2008 yılında 4,5 milyar dolar olan turizm harcaması, 2018 yılında 4,9'a yükselmiştir. Elde edilen artış oranı diğer ülkeler ile kıyaslandığında, Birleşik Krallık hariç en düşük artış oranını ortaya koymaktadır. Uluslararası turizme katılım kapsamında ise Türkiye, son on bir yılda istikrarlı bir artış yakalayamasa da genel olarak bir artış yaşamıştır. Buna göre Türkiye' de, 2008 yılında uluslararası turizme katılım 4,8 milyon iken, 2018 yılında 8,3 milyona yükselmiştir. Sonuçlar, Türkiye'nin uluslararası turizme katılan kişi sayısında kademeli bir artış yaşadığını ortaya koymaktadır.

En fazla uluslararası turizm harcaması yapan ülkeler ile Türkiye'nin GSYH miktarlarına bakıldığında, ABD ve Çin'in en yüksek miktarlara sahip olduğu görülmektedir. Fakat kişi başına düşen GSYH verileri, ABD (62,794 \$) ile Avustralya'nın (57,373 \$) en yüksek değerlere sahip ülkeler olduğunu göstermektedir. Çin, GSYH miktarı olarak, ABD'den sonra ikinci sırada yer almasına rağmen, kişi başına düşen GSYH miktarı Türkiye'den sonra en az olan ülke konumundadır. Türkiye'nin sahip olduğu kişi başına düşen GSYH miktarı ise, en fazla uluslararası turizm harcaması yapan ülkeler ile kıyaslandığında en düşük miktara sahiptir.

Seyahat ve rekabet edebilirlik endeksi sonuçlarına bakıldığında ise, Türkiye'nin sahip olduğu en iyi sıralama kültürel kaynaklar ve iş seyahati (17. sıra) iken, en kötü sıralama da çevresel sürdürülebilirlik alanına (126. sıra) aittir. Buradan hareketle, çevresel sürdürülebilirlik konusunda ciddi önlemlerin alınması gerekmektedir. Çünkü turistlerin destinasyon seçiminde çevre ve sürdürülebilirlik gibi konular da göz önünde bulundurulmaktadır.

Son olarak, diğer ülkelere kıyasla, Türkiye'deki işsizlik oranının yüksek olması, eğitim durumunun çok düşük olması, çalışma saatlerinin fazla olması, seyahat ve turizm harcamalarına ayrılan miktarın düşük olması gibi nedenlerden dolayı turizm sektörüne yönelik oluşturulacak politikalarda söz konusu sosyal, kültürel ve ekonomik faktörlere ağırlık verilmesi gereklilik arz etmektedir. Çalışma kapsamında, Türkiye'nin Akdeniz çanağındaki diğer ülkeler ile rekabet edebilmesi için aşağıda belirtilen hususlar başta olmak üzere çeşitli politikaların geliştirilmesi önerilmektedir.

Seyahat ve turizm rekabet edebilirlik endeksi kapsamında ön plana çıkan ve Avrupa ülkelerinde hızlı bir biçimde yayılan bilgi ve iletişim teknolojileri alanında Türkiye'nin de yatırım yapması önerilmektedir. Teknolojinin gelişmesi ile birlikte, akıllı teknolojiler turizm sektöründe sıklıkla kullanılmaya başlamıştır. Sektörde özellikle robotlar, büyük veri, nesnelerin interneti, arttırılmış gerçeklik ve beacons gibi teknolojiler ön plana çıkmaktadır. Restoranlarda akıllı menüler, online siparişler ve robotik hizmetler kullanılmaya 
başlamıştır. Ayrıca otellerde, müzelerde, seyahat acentelerinde, taşımacılık alanında vb. birçok alanda akıllı uygulamalar sayesinde ziyaretçilerin kolaylıkla hizmet alması sağlanmıştır. Dünyadaki gelişmelerin teknoloji tabanlı yaşanması ülkelerin bu noktada da entegre olmasını gerekli kılmaktadır. Veriler, Türkiye'nin diğer Avrupa ülkelerine göre teknolojik altyapı olarak geride kaldığını göstermektedir. Bu nedenle, sektörde uygulanacak yeni politikaların bilgi ve iletişim teknolojileri çerçevesinde ele alınması gerek kamu kurum ve kuruluşlarına gerekse de turizm işletmelerine önerilmektedir.

$\checkmark$ Rekabet edebilirlik açısından Türkiye'nin diğer ülkelere kıyasla geride kaldığı başka bir nokta ise çevresel ve sürdürülebilir politikaların turizm sektöründe uygulanmasıdır. Bu çerçevede, Kültür ve Turizm Bakanlığı Türkiye'deki otellere çevreye duyarlı tesis belgesi vermektedir. Bakanlığın verilerine göre, Türkiye'de çevreye duyarlı 291 adet beş yıldızlı tesis bulunmaktadır. Bu tesislerin sayılarının artması beklenmektedir. Çünkü gelişen ve değişen dünyada turistlerin, daha bilinçli ve çevresel hassasiyetlerinin daha yüksek olduğu görülmektedir. Son dönemlerde, turistlerin otel tercihlerinde yer alan kriterler arasında sürdürülebilir işletme olması da yer almaktadır. Türkiye'nin bu noktada da gerekli önlemleri alması önerilmektedir.

$\checkmark$ Seyahat ve rekabet edebilirlik endeksi kapsamında Türkiye'nin diğer Avrupa ülkelerine kıyasla dezavantajlı olduğu konuların başında güvenlik konusu gelmektedir. Türkiye'nin turizmden daha fazla pay alabilmesi ve rekabet edebilmesi açısından turistlere güvenli bir ortam sağlaması gerekmektedir. Türkiye özelinde inceleme yapıldığında, Orta Doğu'da yaşanan krizlerin de ülke güvenliğini olumsuz etkilediği söylenebilir. Turistler, kendilerini güvende hissettikleri bölgelere seyahat etme eğilimindedir. Türkiye'nin coğrafi durumu ve içinde bulunulan küresel kriz güvenlik kaygısını da beraberinde getirmektedir. Bu tablodan olumsuz etkilenmemek için Avrupa ülkelerine Türkiye'nin güvenli bir ülke olduğu anlatılmalıdır. Turistlerin gittikleri destinasyonlarda güvenliklerinin sağlanması başlı başına kolluk kuvvetlerine bağlı bir durum olarak görülmemelidir. Bu noktada, yerel halkın sahip olduğu turizm bilinci ve eğitimi aktif rol oynamaktadır. Eğitime ayrılan bütçenin arttırılması, yerel halkta turizm bilincinin oluşturulması için gerekli eğitimlerin ve seminerlerin düzenlenmesi gibi birtakım önlemler alınması önerilmektedir.

$\checkmark \quad$ Turizm sektörü, dünya genelinde en önemli istihdam oluşturan sektörlerden birisi olmuştur. Seyahat ve Turizm Konseyi'nin raporu, dünyadaki her 10 kişiden 1'inin turizm sektöründe çalıştığını ortaya koymaktadır. İstihdam için böylesine önemli bir sektöre yatırım yapılması işsizlik oranlarını düşürecektir. Türkiye'nin işsizlik oranları ile rekabet halinde olduğu ülkelerdeki işsizlik oranları karşılaştırıldığında olumsuz bir tablo ile karşılaşılmaktadır. Bu tablonun olumluya dönüşmesi için turizm yatırımlarının teşvik edilmesi gerekmektedir. Turizm sektörüne yapılacak olan yatırım çarpan etkisiyle birlikte beraberinde birçok yardımcı sektörü de etkileyecektir. Özellikle küresel ölçekte yaşanan ekonomik krizler, bu yatırımların önünü kesebilmektedir. Fakat krizlerden kurtulabilmenin en önemli faktörlerinden birisi de üretim yapabilmektir. Üretim hacmi geniş ve güçlü sanayiye sahip ülkeler bu krizlerden daha az hasarla kurtulabilmektedir. Türkiye gibi gelişmekte olan ülkelerde ise bu kriz ortamı daha derinden hissedilebilmektedir. Bu sonuçlar beraberinde uluslararası turizm harcamaların ve uluslararası turizme katılanların sayısını olumsuz etkilemektedir. Bu nedenle, ülkede yapılacak yatırımların öncelikle üretim alanlarına aktarılması önerilmektedir.

$\checkmark$ Çalışma süreleri bakımından inceleme yapıldığında ise, Türkiye ve Kore'nin en fazla çalışma sürelerine sahip ülkeler olduğu belirlenmiştir. Oysaki turizm gibi hizmet sektöründe çalışan personelin verimliliğini arttırmak için çalışma saatleri düşürülmelidir. Personellerin izinleri zamanında kullandırılmalıdır. Turizm sektöründe, ideal çalışma sürelerine uyulmaması verimliliği düşürmekte ve hizmet kalitesini olumsuz etkilemektedir. Doğal olarak bu süreç, 
turistlerin tekrar satın alma veya tavsiye etme süreçlerine de etki etmektedir. Bu nedenle turizm işletmelerine, çalışma süreleri noktasında hassas olmaları ve işçilerin verimliliklerini arttırmaları önerilmektedir.

En fazla uluslararası turizm harcaması yapan ülkeler ile Türkiye'nin sosyal, kültürel ve ekonomik göstergelerinin karşılaştırmalı olarak incelendiği bu çalışma, söz konusu ülkeler ile sınırlı kalmaktadır. Araştırmacılara, ülkelerin bölgelere ayrılarak değerlendirilmesi, barış ve terör endeksleri gibi farklı endeksler kapsamında, ülkeler arasında inceleme ve karşılaştırma yapılması önerilmektedir. Ayrıca 2019 yılı sonunda Çin'in Hubei eyaletinin Wuhan şehrinde etiyolojisi bilinmeyen pnömoni vakaların bildirilmesiyle başlayan virüs salgını, 2020 yılı ile birlikte hızla diğer kıtalara da yayılarak pandemi haline gelmiştir. COVID-19 (SARS-CoV-2 Enfeksiyonu) olarak ifade edilen pandemi, diğer tüm sektörleri etkilediği gibi turizm sektörünü de olumsuz etkilemiştir. Çok kısa bir sürede küresel bir kriz haline gelen bu salgının ülkeler üzerinde özellikle sosyal ve ekonomik açıdan yıkıcı etkiler bırakacağı şimdiden öngörülmektedir. Bu nedenle, son dönemlerde gelişen bu salgının uluslararası turizm harcamalarına ve turist sayılarına olan etkilerinin ülkeler bazında incelenmesi literatüre katkı sağlayacaktır.

\section{KAYNAKÇA}

Abbruzzo, A., Brida, J. G. and Scuderi, R. (2014). Determinants of Individual Tourist Expenditure as a Network: Empirical Findings from Uruguay, Tourism Management, 43: 36-45.

Agarwal, V. B. and Yochum, G. R. (1999). Tourist Spending and Race of Visitors, Journal of Travel Research, 38(2): 173-176.

Aguilar, M. I., and Diaz, B. (2019). Length of Stay of International Tourists in Spain: A Parametric Survival Analysis, Annals of Tourism Research, 79: 1-14.

Aguilo, E., Rossello, J. and Vila, M. (2017). Length of Stay and Daily Tourist Expenditure: A Joint Analysis, Tourism Management Perspectives, 21: 10-17.

Alegre, J., Mateo, S. and Pou, L. (2013). Tourism Participation and Expenditure by Spanish Households: The Effects of The Economic Crisis and Unemployment, Tourism Management, 39: $37-49$.

Altunışık, R., Coşkun, R., Bayraktaroğlu, S. ve Yıldırım, E. (2010). Sosyal Bilimlerde Araştırma Yöntemleri SPSS Uygulamalı. Sakarya: Sakarya Yayıncılık.

Asgary, N., Santos, G., Vincent, V. and Davila, V. (1997). The Determinants of Expenditures by Mexican Visitors to the Border Cities of Texas, Tourism Economics, 3(4): 319-328.

Bernini, C. and Cracolici, M. F. (2015). Demographic Change, Tourism Expenditure and Life Cycle Behaviour, Tourism Management, 47: 191-205.

Brida, J. G. and Scuderi, R. (2013). Determinants of Tourist Expenditure: A Review of Micro Econometric Models, Tourism Management Perspectives, 6: 28-40.

Cannon, T. F. and Ford, J. (2002). Relationship of Demographic and Trip Characteristics to Visitor Spending: An Analysis of Sports Travel Visitors across Time, Tourism Economics, 8(3): 263-271.

Chhabra, D., Sills, E. and Rea, P. (2002). Tourist Expenditures at Heritage Festivals, Event Management, 7(4): 221-230.

D'urso, P., Disegna, M. and Massari, R. (2020). Satisfaction and Tourism Expenditure Behavior, Social Indicators Research, 147(1): 1-26. 
Downward, P. and Lumsdon, L. (2003). The Demand for Day-Visits: An Analysis of Visitor Spending, Tourism Economics, 6(3): 251-261.

Downward, P. and Lumsdon, L. (2004) Tourism Transport and Visitor Spending: A Study in the North York Moors National Park, UK, Journal of Travel Research, 42(4): 415-420.

EBSO (Ege Bölgesi Sanayi Odası). (2020). 2019 Yılında Dünya ve Türkiye Ekonomisi \& 2020 Yllindan Beklentiler. [Online] http://www.ebso.org.tr/ebsomedia/documents/2019-yilindadunya-ve-turkiye-ekonomisi-\&-2020-yilindan-beklentiler-_69645550.pdf> [Erişim Tarihi: 01.04.2020].

Eugenio-Martin, J. L. and Campos-Soria, J. A. (2011). Income and The Substitution Pattern Between Domestic and International Tourism Demand, Applied Economics, 43(20): 2519-2531.

Eugenio-Martin, J. L. and Campos-Soria, J. A. (2014). Economic Crisis and Tourism Expenditure Cutback Decision, Annals of Tourism Research, 44: 53-73.

Eugenio-Martin, J. L. and Inchausti-Sintes, F. (2016). Low-Cost Travel and Tourism Expenditures, Annals of Tourism Research, 57: 140-159.

Fredman, P. (2008). Determinants of Visitor Expenditures in Mountain Tourism, Tourism Economics, 14(2): 297-311.

Gholipour, H. F. and Tajaddini, R. (2014). Cultural Dimensions and Outbound Tourism, Annals of Tourism Research, 49: 203-205.

Gholipour, H. F., Tajaddini, R. and Al-mulali, U. (2014). Does Personal Freedom Influence Outbound Tourism?, Tourism Management, 41: 19-25.

Gomez-Deniz, E. and Perez-Rodriguez, J. V. (2018). Modelling Distribution of Aggregate Expenditure on Tourism, Economic Modelling, 78: 293-308.

Hong, G. S., Morrison, A. M. and Cai, L. A. (1996). Household Expenditure Patterns for Tourism Products and Service, Journal of Travel \& Tourism Marketing, 4(4): 15-40.

http://www.export.gov/hongkong/eg_hk_048866.asp> [Erişim Tarihi: 03.04.2020].

http://www.kto.visitkorea.or.kr/eng/tourismStatics/keyFacts/KoreaMonthlyStatistics/eng/inout/ inout.kto> [Erişim Tarihi: 07.04.2020].

http://www.russtd.com/official-data.-statistics-of-the-departure-of-russians-abroad-in2019.html> [Erişim Tarihi: 05.04.2020].

http://www.tradingeconomics.com/analytics/indicators.aspx> [Erişim Tarihi: 03.04.2020].

http://www.weforum.org/docs/WEF_TheGlobalCompetitivenessReport2019.pdf> [Erişim Tarihi: 03.03.2020].

http://www.worldometers.info> [Erişim Tarihi: 03.04.2020].

https://www.ceicdata.com/en/indicators> [Erişim Tarihi: 03.04.2020].

https://www.data.worldbank.org/indicator> [Erişim Tarihi: 10.03.2020].

https://www.destinationnsw.com.au/wp-content/uploads/2019/09/tourism-research-australiatourism-forecast-report-2019.pdf> [Erişim Tarihi: 03.04.2020].

https://www.prnewswire.com/news-releases/travel-and-tourism-in-france-to-2019-

300164182.html> [Erişim Tarihi: 07.04.2020]. 
https://www.statista.com/topics/3826/outbound-tourism-in-european-countries> [Erişim Tarihi: 03.04.2020].

https://www.store.globaldata.com/report/tt0127mi--tourism-source-market-insights-franceanalysisof-tourist-profile-traveler-flows-spending-patterns-main-destination-markets-and-risksand-opportunities> [Erişim Tarihi: 03.04.2020].

https://www.unwto.org/international-tourism-growth-continues-to-outpace-the-economy> [Erişim Tarihi: 10.03.2019].

https://www.ustravel.org/research/us-travel-outlook> [Erişim Tarihi: 05.04.2020].

https://www150.statcan.gc.ca/n1/daily-quotidien/190723/dq190723a-eng.htm> [Erişim Tarihi: 07.04.2020].

Hung, W. T., Shang, J. K. and Wang, F. C. (2012). Another Look at The Determinants of Tourism Expenditure, Annals of Tourism Research, 39(1): 495-498.

Jang. S., Bai, B., Hong, G. S., O'Leary, J. T. (2004). Understanding Travel Expenditure Patterns: A Study of Japanese Pleasure Travelers to The United States by Income Level, Tourism Management, 25: 331-341.

Kim, S. S. and Prideaux, B. (2005). Marketing Implications Arising from a Comparative Study of International Pleasure Tourist Motivations and Other Travel-Related Characteristics of Visitors to Korea, Tourism Management, 26(3): 347-357.

Kim, S. S., Han, H. and Chon, K. (2008). Estimation of the Determinants of Expenditures by Festival Visitors, Tourism Analysis, 13(4): 387-401.

Konstantakis, K. N., Soklis, G. and Michaelides, P. G. (2017). Tourism Expenditures and Crisis Transmission: A General Equilibrium Gvar Analysis with Network Theory, Annals of Tourism Research, 66: 74-94.

Kozak, M., Gokovali, U. and Bahar, O. (2008). Estimating the Determinants of Tourist Spending: A Comparison of Four Models, Tourism Analysis, 13(2): 143-156.

Larsen, S. and Wolff, K. (2019). In Defense of The Domestic Tourist a Comparison of Domestic and International Tourists' Revisit-Intentions, Word-of-Mouth Propensity, Satisfaction and Expenditures, Scandinavian Journal of Hospitality and Tourism, 19(4-5): 422-428.

Lin, V. S., Mao, R. and Song, H. (2015). Tourism Expenditure Patterns in China, Annals of Tourism Research, 54: 100-117.

Mak, J., Moncur, J. and Yonamine, D. (1977). How or How Not to Measure Visitor Expenditures, Journal of Travel Research, 16(1): 1-4.

Marcussen, C. (2011). Determinants of Tourist Spending in Cross Sectional Studies and at Danish Destinations, Tourism Economics, 17(4): 833-855.

Marrocu, E., Paci, R. and Zara, A. (2015). Micro Economic Determinants of Tourist Expenditure: A Quantile Regression Approach, Tourism Management, 50: 13-30.

Mehran, J. and Olya, H. G. T. (2018). Progress on Outbound Tourism Expenditure Research: A Review, Current Issues in Tourism, 22(20): 2511-2537.

Mihalic, T. (2002). Tourism and Economic Development Issues, (Editor) Sharpley, R. and D. Telfer, D.: Include Tourism and Development: Concepts and Issues (pp.81-111) Clevedon, UK: Channel View Publications. 
Mok, C. and Iverson, T. J. (2000). Expenditure-Based Segmentation: Taiwanese Tourists to Guam, Tourism Management, 21(3): 299-305.

Nunes Valença, M., de Souza Melo, A., Falcao Sobral, M. F. and Pinto Xavier, M. G. (2015). Relationship Between the Exchange Rate and The Tourism Sector: Analysis by Vector Autoregression, Revista Turismo, 17(3): 737-757.

Olya, H. G. T. and Mehran, J. (2017). Modelling Tourism Expenditure Using Complexity Theory, Journal of Business Research, 75: 147-158.

Perez, E. A. and Juaneda, S. C. (2000). Tourist Expenditure for Mass Tourism Markets, Annals of Tourism Research, 27(3): 624-637.

Perez-Rodriguez, J. V. and Ledesma-Rodriguez, F. (2019). Unconditional Quantile Regression and Tourism Expenditure: The Case of the Canary Islands, Tourism Economics, 25(8): 1-23.

Qiang, M., Shen, M. and Xie, H. (2019). Loss of Tourism Revenue Induced by Coastal Environmental Pollution: A Length-of-Stay Perspective, Journal of Sustainable Tourism, 28(4): 550567.

Rahman, N., Ng, S. H., Ramachandran, S., Wang, D. D., Sridharan, S., Tan, C. S., Khoo, A. and Tan, X. Q. (2019). Drivers of Hospital Expenditure and Length of Stay in an Academic Medical Centre: A Retrospective Cross-Sectional Study, BMC Health Services Research, 19(442): 1-16.

Rossello-Nadal, J. and He, J. (2019). Tourist Arrivals Versus Tourist Expenditures in Modelling Tourism Demand, Tourism Demand-Emerging Theoretical and Empirical Issues, Special Issue: 1-16.

Rudkin, S. and Sharma, A. (2019). Live football and Tourism Expenditure: Match Attendance Effects in the UK, European Sport Management Quarterly, 20: 1-25.

Silik, C. E. ve Ünlüönen, K. (2018). Hizmet Kalitesi, Müşteri Memnuniyeti ve Tavsiye Etme Niyeti Arasındaki İlişki: Kayak Merkezlerine Yönelik Bir İnceleme, İşletme Araştırmaları Dergisi, 10(4): 333-357.

Taylor, D. T., Fletcher, R. R. and Clabaugh, T. (1993). A Comparison of Characteristics, Regional Expenditures, and Economic Impact of Visitors to Historical Sites with Other Recreational Visitors, Journal of Travel Research, 32(1): 30-35.

Thrane, C. (2002). Jazz Festival Visitors and Their Expenditures: Linking Spending Patterns to Musical Interest, Journal of Travel Research, 40(3): 281-286.

Thrane, C. (2015). Students' Summer Tourism: An Econometric Analysis of Trip Costs and Trip Expenditures, Tourism Management Perspectives, 15: 65-71.

Thrane, C. and Farstad, E. (2011). Domestic Tourism Expenditures: The Non-Linear Effects of Length of Stay and Travel Party Size, Tourism Management, 32: 46-52.

Thrane, C. and Farstad, E. (2012). Nationality as a Segmentation Criterion in Tourism Research: The Case of International Tourists' Expenditures While on Trips in Norway, Tourism Economics, 18(1): 203-217.

UNWTO (Birleşmiş Milletler Dünya Turizm Örgütü) (2020). World Tourism Barometer. [Online] https://www.e-unwto.org/doi/pdf/10.18111/wtobarometereng.2020.18.1.1, [Erişim Tarihi: 02.04.2020].

Vietze, C. (2011). What's Pushing International Tourism Expenditures?, Tourism Economics, 17(2): 237-260. 
Wang, Y. and Davidson, M. C. (2010). A Review of Micro Analyses of Tourist Expenditure, Current Issues in Tourism, 13(6): 507-524.

Wang, Y. S. (2014). Effects of Budgetary Constraints on International Tourism Expenditures, Tourism Management, 41: 9-18.

Wang, Y., Rompf, P., Severt, D. and Peerapatdit, N. (2006). Examining and Identifying the Determinants of Travel Expenditure Patterns, International Journal of Tourism Research, 8(5): 333347.

Wanke, P., Figueiredo, O. H. S. and Antunes, J. J. M. (2019). Unveiling Endogeneity and Temporal Dependence Between Tourism Revenues/Expenditures and Macroeconomic Variables in Brazil: A Stochastic Hidden Markov Model Approach, Tourism Economics, 25(1): 3-21.

Wei, X., Huang, S., Yap, G., Wu, X. and Taivan, A. (2018). The Influence of National Holiday Structure on Domestic Tourism Expenditure: Evidence from China, Tourism Economics, 24(7): 781800 .

Witt, S. F. and Witt, C. A. (1995). Forecasting Tourism Demand: A Review of Empirical Research, International Journal of Forecasting, 11(3): 447-475. 